Article

\title{
Fibrillarin Ribonuclease Activity is Dependent on the GAR Domain and Modulated by Phospholipids
}

\author{
Francisco Guillen-Chable ${ }^{1}\left(\mathbb{D}\right.$, Ulises Rodríguez Corona ${ }^{1}$, Alejandro Pereira-Santana ${ }^{2,3}{ }^{\circledR D}$, \\ Andrea Bayona ${ }^{1}$, Luis Carlos Rodríguez-Zapata ${ }^{4}\left({ }^{\circledR}\right.$, Cecilia Aquino ${ }^{1} @$, Lenka Šebestová ${ }^{5,6}$,
} Nicolas Vitale ${ }^{7}$, Pavel Hozak ${ }^{5}($ i) and Enrique Castano $1, *(\mathbb{B})$

1 Biochemistry and Molecular Plant Biology Department, Centro de Investigación Científica de Yucatán, A.C. Calle 43 No. 130, Colonia Chuburná de Hidalgo, Mérida C.P. 97200, Yucatán, Mexico; francisco.guillen@cicy.mx (F.G.-C.); Ulises.RodriguezCorona@ircm.qc.ca (U.R.C.); andrea.bayona.her@gmail.com (A.B.); cecilia.aquino-perez@img.cas.cz (C.A.)

2 Industrial Biotechnology Department, Centro de Investigación y Asistencia en Tecnología y Diseño del Estado de Jalisco, A.C., Camino Arenero 1227, el Bajio, Zapopan C.P. 45019, Jalisco, Mexico; apereira@ciatej.mx

3 Dirección de Cátedras, Consejo Nacional de Ciencia y Tecnología, Av. Insurgentes Sur 1582, Alcaldia Benito Juarez C.P. 03940, Ciudad de Mexico, Mexico

4 Biotechnology Department, Centro de Investigación Científica de Yucatán, A.C. Calle 43 No. 130, Colonia Chuburná de Hidalgo, Mérida C.P. 97200, Yucatan, Mexico; lcrz@cicy.mx

5 Department of Biology of the Cell Nucleus, Institute of Molecular Genetics of the CAS, v.v.i., Videnska 1083, 14220 Prague, Czech Republic; lenka.sebestova@img.cas.cz (L.Š.); pavel.hozak@img.cas.cz (P.H.)

6 Faculty of Science, Charles University, Albertov 6, 12800 Prague, Czech Republic

7 Institute of Celullar and Integrative Neuroscience (INCI), UPR-3212 The French National Centre for Scientific Research \& University of Strasbourg, 67000 Strasbourg, France; vitalen@unistra.fr

* Correspondence: enriquec@cicy.mx

Received: 26 March 2020; Accepted: 29 April 2020; Published: 6 May 2020

check for updates

\begin{abstract}
Fibrillarin is a highly conserved nucleolar methyltransferase responsible for ribosomal RNA methylation across evolution from Archaea to humans. It has been reported that fibrillarin is involved in the methylation of histone $\mathrm{H} 2 \mathrm{~A}$ in nucleoli and other processes, including viral progression, cellular stress, nuclear shape, and cell cycle progression. We show that fibrillarin has an additional activity as a ribonuclease. The activity is affected by phosphoinositides and phosphatidic acid and insensitive to ribonuclease inhibitors. Furthermore, the presence of phosphatidic acid releases the fibrillarin-U3 snoRNA complex. We show that the ribonuclease activity localizes to the GAR (glycine/arginine-rich) domain conserved in a small group of RNA interacting proteins. The introduction of the GAR domain occurred in evolution in the transition from archaea to eukaryotic cells. The interaction of this domain with phospholipids may allow a phase separation of this protein in nucleoli.
\end{abstract}

Keywords: nucleolus; ribonucleolar particle; rRNA; fibrillarin; phosphoinositides; viral progression

\section{Introduction}

The nucleolus is a well-studied nuclear structure which has been shown for a long time to separate into three components depending on the particular step of ribosome biogenesis: the fibrillar center (FC) where RNA pol I is found, the dense fibrillar component (DFC) where protein fibrillarin is concentrated, and the granular component (GC) that is enriched in nucleophosmin (NPM1) $[1,2]$. The nucleolar proteome consists of hundreds of different proteins, as well as a large set of different types of RNA that need to be in a particular compartment in order to carry their function [3]. All these components form a multi-layer core found in a liquid gel structure. The nucleolar assembly is controlled 
in a concentration-dependent phase transition, as shown earlier by [4], where the nucleoli behave as multi-component liquid-phase droplets ruled by thermodynamic forces [5]. An elegant set of experiments using a microfluidic device showed the phase dynamics of fibrillarin and other nucleolar components [6]. Furthermore, the composition, morphology, and fusion dynamics of nucleoli are altered by ATP depletion, as shown using fibrillarin-GFP in a lapse movie. Thus, fibrillarin condensates into dozens of small droplets throughout the nucleus [7]. Transcription of pre-ribosomal RNA at active nucleolar organizer regions (NORs) lowers the critical concentration for phase separation of nucleolar proteins, such as fibrillarin and NPM1, and nucleates the assembly of the fibrillarin-rich DFC [8]. The spatial separation of the nucleolar sub-compartments is dictated by differences in their viscoelastic properties, especially in the surface tensions of the fibrillarin- and NPM1-rich phases with respect to the surrounding nucleoplasm [9].

Fibrillarin in eukaryotic organisms contains a glycine/arginine-rich domain (GAR), a spacer region called BCO, a central domain with RNA binding motif, and an alpha helix domain [10,11]. Fibrillarin is an essential 2'-O-methyltransferase for all eukaryotes, mediating the methylation of rRNA and histone $\mathrm{H} 2 \mathrm{~A}$ at a glutamine in position 104 in humans and 105 in yeast required for the epigenetic regulation of ribosomal genes [12,13]. Fibrillarin is important in ribosome biogenesis and also plays a role in other processes, including viral progression. RNA viruses like coronavirus, infectious bronchitis virus (IBV), influenza, and human immunodeficiency virus (HIV) require fibrillarin for cell to cell infection, both in plants and humans [10,14-16]. Fibrillarin is known to associate with different nuclear and nucleolar RNAs (U3, U8, U13, U14, U60, x, y, snR3, snR4, snR8, snR9, snR10, snR11, snR30, snR189, and snR190) $[1,17]$ and other proteins to form a variety of snoRNPs. The best-characterized and most studied snoRNP is composed of the small nucleolar RNA (snoRNA) U3. snoRNA U3 is involved as a guide RNA in the initial steps of pre-rRNA processing [18] and cleavage that leads to the maturation of 18S rRNA [19]. For this early processing, several factors, such as fibrillarin, nucleolin, and the U14 snoRNA, are required [20-22]. It has been suggested that liquid-liquid phase separations (LLPSs) are implicated in synthesis and processing modifications during ribosomal production. Phase separation has been observed in proteins that contain intrinsically disordered regions (IDRs) in their sequences [23,24], i.e., fibrillarin, nucleolin, and Gar1 proteins, contain IDR. LLPS in this process ensures a membrane-less environment for the production and highly ordered process of ribosome assembly. Earlier results indicate that fibrillarin can bind to phosphatidylinositol 4,5-bisphosphate (PIP2). Lipids play crucial roles in nuclear function and dynamic architecture, and fibrillarin is involved in the lipid phase and RNA binding in the cell [25-27].

Phosphoinositide pathways are regulated by several enzymes in both cytosol and the nucleus. Each of the seven different phosphorylated phosphoinositides [28] is known to localize in different parts of the cell [29]. Therefore, a particular environment for these phosphoinositides, together with their partners, can be in a particular phase that can be differentiated by metabolic changes in the lipids. This hypothesis involves a specific localization for a protein-lipid complex together with a particular function that can be altered by lipid metabolism and thus results in a re-localization of the components or alteration of complex formation, leading to the movement of some components due to the biochemical properties of the new lipids. We are still far from showing that RNA, lipids, and proteins can organize in particular structures that can phase separate by means of lipid metabolism and posttranslational protein modifications. However, such processes would reduce the energy requirements needed for cells to organize particular structures and to relocate particular complexes upon phosphorylation changes in the lipids. Dynamic proteins like fibrillarin are intriguing subjects to test as they are known to exist in particular phase separation. However, their link to structural changes by RNA alteration suggests that this component is also essential for proper localization, as during RNA inhibition [30]. Therefore, fibrillarin localization is not a simple phase separation that requires a protein-lipid complex, but also RNA to have a functional role through ribosome biogenesis.

Here we show that fibrillarin has a ribonuclease activity for rRNA, and this general activity is blocked when it is bound to snoRNA U3. The ribonuclease activity of fibrillarin is carried by the GAR 
domain, which is also responsible for interaction with different phosphoinositides. Moreover, we also show that the ribonuclease activity of fibrillarin increases with phosphatidylinositol 5-phosphate (PI5P) and reduces in the presence of phosphatidic acid (PA) or during binding to Guide RNA U3. Ribonucleases are involved in vital cellular functions, including cytoplasmic and nuclear RNA degradation, RNAi, antiviral defense, DNA synthesis, and RNA processing [31-35]. Pre-rRNA maturation involves the activity of specific RNases and RNA modifying enzymes to achieve functional rRNA [36,37]. Most pre-rRNA processing is mediated by the co-transcriptional association of nascent transcripts with ribosomal proteins (RP) and several small nucleolar ribonucleoprotein particles (snoRNP) containing fibrillarin [38].

\section{Materials and Methods}

\subsection{Cell Lines, Cell Culture, and Transfection Assays}

HeLa cells were cultured as previously published [25]; transient transfection was performed at $80 \%$ confluence using polyethylenimine (PEI) with $10 \mu \mathrm{g}$ of plasmid DNA in $1 \mathrm{~mL}$ of Dulbecco's modified Eagle medium (DMEM) without fetal calf serum. Distribution patterns of the wild type and fibrillarin mutants, coupled with GFP reporter, were analyzed in 200 cells for at least three separate experiments. Plasmid DNA for transfections was purified from bacterial cultures using maxiprep columns (QIAGEN, Hilden, Germany).

A stable SNAP-tag-Fib cell line was generated as follows: transfection with PEI was performed in an $80 \%$ confluence $60-\mathrm{mm}$ plate of U2OS osteosarcoma cell line. The cocktail for transient transfection (1.5 $\mu$ g of pfSNAP-tag-fibrillarin plasmid DNA and $9 \mu \mathrm{L}$ of PEI) was incubated for $15 \mathrm{~min}$ at RT and added dropwise. After 48 hours of transfection, $1000 \mu \mathrm{g} / \mathrm{mL}$ of geneticin G-418 of Sigma-Aldrich $® w a s$ added and incubated for 9 days. The selection of positive transfected colonies was made after washing the dead cells with PBS and changing the culture media. Cells were stained with a fluorescent substrate that can be used to label SNAP-tag®fusion proteins, and positive colonies were selected prior to use in a bigger culture. The fluorescent substrate used for this work was SNAP-Cell $₫$ Oregon Green $₫$. Specific primary anti-PIP2 from Echelon ${ }^{\mathrm{TM}}$ (Z-A045) was used for immunofluorescence detection of PIP2 and labeled by anti-mouse IgM secondary antibody conjugated with Alexa Flour $§ 555$ from Life Sciences. The PA sensor Spo20p-GFP was described previously [39].

\subsection{Microscopy}

Wide-field microscopy was performed on a Leica DM6000 (Leica Microsystems, Wetzlar, Germany; filter cubes: DAPI (Ex: 360/40, Em: 470/40), FITC (Ex: 480/40; Em: 527/30), TRITC (Ex: 546/12; Em: 600/40), Cy5 (Ex: 620/60; Em: 700/75)) using an HCX PL APO 100x/1.40-0.70 OIL objective, a Leica EL6000 with an HXP 120W/45C Vis Hg light source, Type F immersion liquid (Leica Microsystems), a Leica DFC350 FX camera, and Las X software.

\subsection{Structured Illumination Microscopy}

Images were acquired using the 3D-SIM system DeltaVision OMX (GE Healthcare Life Sciences, Marlborough, MA, USA) with PLAN APO N 60x/1.42 OIL objective, a 4x pco.edge 5.5 sCMOS camera and DeltaVision OMX (Buckinghamshire, UK) controlling software. Lasers with wavelengths 405, 488, 568, and 642 nm with filters for DAPI (Ex: 395.5/29; Em: 435.5/31), FITC (Ex: 477/32; Em: 528/48), and Alexa Fluor 568 (Ex: 571/19; Em: 609/37). Immersion oil laser liquid (Cargille Laboratories, Cedar Grove, NJ, USA; Code: 5610; $\mathrm{n}=1.5160$ ). Image reconstruction and registration were processed with DeltaVision softWoRx 6.5.2. software. Wiener filters were set to 0.001. Samples were mounted to $90 \%$ glycerol supplemented with $5 \% \mathrm{~N}$-propyl gallate. 


\subsection{Cloning}

Total RNA from U2OS cells was extracted with RiboZol ${ }^{\mathrm{TM}}$ (Solon, OH, USA), following the manufacturer's instructions. The sequences from fibrillarin, GAR1, and SLM14 were obtained using cDNA from the reverse transcriptase strategy of TaqMan ${ }^{\mathrm{TM}}$ and amplified by DreamTaq ${ }^{\mathrm{TM}}$ polymerase (Thermo Fisher Scientific, Waltham, MA, USA), following the provider's instructions. The gene encoding fibrillarin (NM_001436.3) was amplified by RT-PCR from total RNA extraction of HeLa cells and cloned into the NcoI and BamHI sites of the pET-15b vector (Fib_Fwd 5'-CCATGGATGAAGCCAGGATTCAGTCCCCGTG-3'; Fib_Rev 5-GGATCCTCAGTTCTTCACCTTGGGGGGTGGC-3'). For protein expression in HeLa cells, the fibrillarin sequence was cloned into the XhoI and BamHI sites of the pEGFP-N1 vector to generate pGFP-FIB. The N-terminal part (amino acids 1 to 134) containing the GAR domain of the fibrillarin was amplified from the pET15b: $\mathrm{HsFib}$ vector (GB_forward 5'-CCATGGATGAAGCCAGGATTCAGTCCC-3'; GB_reverse 5'-CTCGAGGTACTCAATTTTGTCATCTCCTTCC-3', and cloned into the NcoI and XhoI sites of the pET42b vector). Once cloned into pET42b, small fragments from fibrillarin were obtained by complete plasmid PCR mutagenesis with the following primers: BCO (Forward 5'-AGAATGTGATGGTGGAGCCGCA-3', reverse pET42b 5' -CCATGGACCCGCGTCCCTCAA-3'); HsGAR domain (Forward pET42b 5'-CTCGAGCACCACCACCACCA-3'; reverse $5^{\prime}$-TCTTCСТССТССТССАCCGCC-3'; and miniGAR (Forward pET42b and reverse 5'-TCACCAAAGCCCCCTCGGCC-3').

The specific primers used for cloning the GAR1 and GAR domains from Lsm14 genes were FwGAR1 5'-CCATGGATATGTCTTTTCGAGGCGGAGG-3', and RvGAR1 $5^{\prime}$-CTCGAGATGTCCTCTCCCTCTGAAACC-3' between NcoI and Xhol restriction sites, respectively. For GAR-Lsm14, the domains were $\mathrm{Fw} 5^{\prime}$-AAGAATTCGATGACAATAGAGAA- $3^{\prime}$ and Rev 5'-TAAGCTTAG GGTCCAAAAGCTGTGCTGT-3' between EcoRV and HindIII restriction sites, respectively.

\subsection{Recombinant Protein Expression and Purification}

Recombinant fibrillarin was expressed in Escherichia coli BL21 gold with $1 \mathrm{mM}$ isopropyl-D-1-thiogalactopyranoside (IPTG) at $25^{\circ} \mathrm{C}$ for $5 \mathrm{~h}$. Harvested cells were resuspended in protein extraction buffer $(500 \mathrm{mM} \mathrm{NaCl}, 25 \mathrm{mM}$ tris $\mathrm{pH} 8,10 \%$ glycerol, $20 \mathrm{mM}$ imidazole, $0.1 \%$ Tween 20, $0.1 \mathrm{mM}$ AEBSF, and $0.1 \mathrm{mM}$ DTT) and broken down by sonication. After clarification by centrifugation $(17,400 \times g$ for $15 \mathrm{~min})$, the supernatant was loaded onto a Ni-NTA agarose column (Thermo Fisher) and washed three times with the extraction buffer and then eluted with a linear gradient from 70 to $200 \mathrm{mM}$ imidazole in BC-100 buffer $(20 \mathrm{mM}$ Tris-HCl buffer, $\mathrm{pH}$ 8, $100 \mathrm{mM} \mathrm{NaCl}, 0.2 \mathrm{mM}$ EDTA, $10 \%$ glycerol) and revised by $15 \%$ SDS-PAGE. The fraction containing fibrillarin was passed through MonoQ sepharose (Amersham Pharmacia, Buckinghamshire UK), utilizing a 0.1 to $0.5 \mathrm{KCl}$ gradient to elute the fibrillarin. Fibrillarin containing fractions were pulled and dialyzed against BC-100 and $0.1 \mathrm{mM}$ AEBSF. After the MonoQ sepharose purification step, the fraction containing fibrillarin was loaded on a MonoS (Amersham Pharmacia) column resin and eluted with a linear gradient from 0.1 to $0.5 \mathrm{M} \mathrm{KCl}$ in BC-100 buffer with $0.1 \mathrm{mM}$ AEBSF. The purity of proteins was revised by $15 \%$ SDSPAGE, followed by silver staining. For peptides cloned into $\mathrm{pET} 42 \mathrm{~b}$ vector, the supernatant was first loaded into a Ni-NTA agarose column followed by loading into a glutathione-sepharose column and eluted with BC-100 buffer with $10 \mathrm{mM}$ of reduced glutathione and $0.1 \mathrm{mM}$ of AEBSF.

Homo sapiens GAR1, Lsm14, HsGAR-Fib, and the viral protein TGB1 were expressed in E. coli Rosetta competent cells. The recombinant production of these proteins was induced with $1 \mathrm{mM}$ IPTG at $25^{\circ} \mathrm{C}$ for $4 \mathrm{~h}$. Induced cells were harvested by centrifugation at $4000 \times g$ for $20 \mathrm{~min}$ at $4{ }^{\circ} \mathrm{C}$, resuspended in lysis buffer ( $50 \mathrm{mM}$ Tris- $\mathrm{HCl} \mathrm{pH}$ 8, $300 \mathrm{mM} \mathrm{NaCl}, 20 \mathrm{mM}$ Imidazole, $10 \%$ glycerol, $0.1 \%$ of Triton X-100) and supplied with $0.1 \mathrm{mM}$ AEBSF and 0.1 DTT as a protease inhibitor to reduce respective agents, then sonicated 10 times with $30 \mathrm{~s}$ ON/30 s OFF cycles. The fragmented cells were 
clarified by centrifugation at $15000 \times g$ for $20 \mathrm{~min}$ at $4{ }^{\circ} \mathrm{C}$, and the supernatant was clarified for the IMAC purification strategy, using $100 \mu \mathrm{L}$ of nickel beads (Thermo Fisher ${ }^{\mathrm{TM}}$ ) and incubated for $30 \mathrm{~min}$ at $4{ }^{\circ} \mathrm{C}$ in a rotor. The column was washed using 10 volumes of beads lysis buffer, along with an increased concentration of $\mathrm{NaCl}$ from 100 to $500 \mathrm{mM}$. The proteins were eluted with $50 \mathrm{mM}$-Tris- $\mathrm{HCl}$ $\mathrm{pH} 8,100 \mathrm{mM} \mathrm{NaCl}$, and $250 \mathrm{mM}$ imidazole and supplied with $10 \%$ glycerol, $0.1 \mathrm{mM}$ AEBSF, and $0.1 \mathrm{mM}$ DTT. All purification steps were done at $4{ }^{\circ} \mathrm{C}$ to reduce proteolysis. Proteins were stored at $-80^{\circ} \mathrm{C}$ until use in the next experimental procedures.

\subsection{Exponential Megaprimer PCR (EMP) Strategy to Introduce the GAR Domain Coding Region into RNP Complex}

Following the EMP strategy [40] to introduce long DNA sequences into plasmids, we cloned the $\mathrm{N}$-domain of fibrillarin into the pLink plasmid containing the coding sequences for NOP56/NOP58, $15.5 \mathrm{~K}$, previously reported by [41], owed to the fact that the coding region of fibrillarin is truncated in amino acid 83, i.e., lacking the GAR domain coding sequence.

For the GAR domain primer synthesis, we used the following primers: FW1-GARFib-EMP: $\quad 5^{\prime}-\quad$ ATGAAGCCAGGATTCAGTCC-3' and RV1-EMP: $5^{\prime}$ GGACTGAATCCTCGCTTCATCACATTCTTCCCCGACTGGT- $3^{\prime}$ in a reaction containing $1 \mathrm{X}$ HF Phusion buffer (Thermo Fisher, CAT F530S), $200 \mu \mathrm{M}$ of each dNTP, $0.5 \mu \mathrm{M}$ primer FW1, $0.5 \mu \mathrm{M}$ primer RV1, $25 \mathrm{ng}$ of pET15b:fibrillarin (with full sequence) as plasmid DNA template, and $0.02 \mathrm{U} / \mu \mathrm{L}$ Phusion DNA polymerase (Thermo Fisher) in a final volume of $50 \mu \mathrm{L}$. Following this, PCR conditions were $98{ }^{\circ} \mathrm{C}, 30 \mathrm{~s}$ as an initial denaturing step, followed by 25 cycles of denaturing $\left(98^{\circ} \mathrm{C}, 10 \mathrm{~s}\right)$, annealing $\left(63^{\circ} \mathrm{C}, 30 \mathrm{~s}\right)$, and extension $\left(72^{\circ} \mathrm{C}, 15 \mathrm{~s}\right)$. The 266 -bp product of the first PCR was analyzed by agarose gel $1 \%$ electrophoresis and purified with the QIAquick Gel Extraction Kit (Qiagen, Hilden, Germany, ID: 28704).

The GAR domain DNA region was introduced with a second PCR using the primers FW1, RV2-GARFib-EMP: 5'-GGATCCCATAGTTAATTTCT-3', and the PCR product from the first PCR (as a mega primer) in a reaction containing 1 X HF Phusion buffer, $200 \mu \mathrm{M}$ of each dNTP, $0.5 \mu \mathrm{M}$ primer FW1, $0.5 \mu \mathrm{M}$ RV2, 25-50 ng mega primer, $25 \mathrm{ng}$ of megaplasmid as a template, and $0.02 \mathrm{U} / \mu \mathrm{L}$ Phusion DNA polymerase (Thermo Fisher ${ }^{\mathrm{TM}}$ ) in a final volume of $50 \mu \mathrm{L}$. The PCR conditions were an initial denaturing step at $98^{\circ} \mathrm{C}$ for $30 \mathrm{~s}, 25$ cycles, with a denaturing step $\left(98^{\circ} \mathrm{C}, 10 \mathrm{~s}\right)$, an annealing step $\left(56^{\circ} \mathrm{C}\right.$ for $\left.30 \mathrm{~s}\right)$, and an extension $\left(72{ }^{\circ} \mathrm{C}\right.$ for $\left.30 \mathrm{~s}\right)$, with no final extension step.

\subsection{In Vitro Ligation and Transformation of the EMP Product}

Using KLD Enzyme Mix from NEB (Cat M0554S), the PCR product from the second reaction was phosphorylated, ligated, and the template DNA removed with kinase, ligase, and DpnI enzymes contained in enzyme mix. The following components were used in a $10-\mu \mathrm{L}$ reaction: $1 \mathrm{X}$ KLD reaction buffer, $1 \mu \mathrm{L}$ KLD enzyme mix, 1-4 $\mu \mathrm{L}$ EMP product, and nuclease-free $\mathrm{H} 20$ up to $10 \mu \mathrm{L}$. The reaction was incubated at $25^{\circ} \mathrm{C}$ for $5 \mathrm{~min}$, with $5 \mu \mathrm{L}$ of the resulting product used for transformation into $50 \mu \mathrm{L}$ chemically competent $E$. coli Top 10 cells.

\subsection{Recombinant RNP Complex Expression and Purification}

Ribonucleoprotein complexes (RNP), with or without the GAR domain sequence, were expressed using E. coli BL21 DE3 competent cells. The induced cells were harvested by centrifugation at $4000 \times g$ for $20 \mathrm{~min}$ at $4{ }^{\circ} \mathrm{C}$, resuspended in lysis buffer $(50 \mathrm{mM}$ Tris- $\mathrm{HCl} \mathrm{pH} 8,300 \mathrm{mM} \mathrm{NaCl}, 20 \mathrm{mM}$ Imidazole, $10 \%$ glycerol, $0.1 \%$ of Triton X-100), and supplied with $0.1 \mathrm{mM}$ AEBSF and 0.1 DTT as protease inhibitor and reducing agent, respectively. The fragmented cells from sonication were clarified by centrifugation at 15000x $\mathrm{g}$ for $20 \mathrm{~min}$ at $4{ }^{\circ} \mathrm{C}$, and the supernatant used for the IMAC purification strategy, as stated above. Imidazole elution was carried out with $50 \mathrm{mM}$-Tris- $\mathrm{HCl} \mathrm{pH}$ 8, $100 \mathrm{mM} \mathrm{NaCl}, 10 \%$ glycerol, and $0.1 \mathrm{mM}$ AEBSF and $0.1 \mathrm{mM}$ DTT. MonoQ purification was carried out to remove the remaining 
contaminants. All purification steps were done at $4{ }^{\circ} \mathrm{C}$ to reduce proteolysis. The proteins were stored at $-80^{\circ} \mathrm{C}$ until use in experimental procedures.

\subsection{SNAP-Tag-Fibrillarin Purification from HeLa Cells}

The media from the HeLa cell cultures was discarded, and the cell monolayer washed twice with cold PBS and the excess discarded. Then, $500 \mu \mathrm{L}$ of buffer A (10 mM HEPES pH 7.9, $10 \mathrm{mM} \mathrm{KCl}, 0.1 \mathrm{mM}$ EDTA, $0.4 \%$ NP-40, $0.5 \mathrm{mM}$ AEBSF, and 0.1 DTT) was added to each plate, the cells were scraped and resuspended with up- and down-pipetting, transferred to a fresh $1.5-\mathrm{mL}$ tube and incubated for $10 \mathrm{~min}$ at room temperature, then centrifugated at $15,000 \times g$ at $4{ }^{\circ} \mathrm{C}$ for $5 \mathrm{~min}$. The cytoplasmic upper layer (supernatant) was stored at $-80^{\circ} \mathrm{C}$. The pellet was resuspended in $150 \mu \mathrm{L}$ of buffer B $(20 \mathrm{mM}$ HEPES pH 7.9, $0.4 \mathrm{M} \mathrm{NaCl}, 1 \mathrm{mM}$ EDTA, 10\% glycerol, $0.5 \mathrm{mM}$ AEBSF, and $0.1 \mathrm{mM}$ DTT) and placed on ice for $2 \mathrm{~h}$, vortexing every $15 \mathrm{~min}$, and then centrifugated at $15,000 \times g$ at $4{ }^{\circ} \mathrm{C}$ for $5 \mathrm{~min}$; the upper layer was stored at $-80^{\circ} \mathrm{C}$ as the nuclear protein fraction. Proteins were visualized in SDS-PAGE. In-vitro labeling with SNAP-Biotin strategy was done following the NEB manufacturer' instructions in a reaction tube: $1 \mathrm{mM}$ DTT, $10 \mu \mathrm{M}$ SNAP-tag substrate, $600 \mu \mathrm{L}$ nuclear protein extract, and volume adjusted with PBS to $800 \mu \mathrm{L}$ with $0.5 \mathrm{mM}$ AEBSF. The tube was incubated at $37^{\circ} \mathrm{C}$ for $30 \mathrm{~min}$ and stored for purification steps. Biotin-streptavidin magnetic beads were used for purification, following the manufacturer's instructions (Thermo Fisher Scientific).

\subsection{Western Blot Assay}

Fibrillarin was loaded in $12 \%$ acrylamide gel to perform SDS-PAGE, then transferred to a nitrocellulose membrane and blocked with $3 \%$ of BSA in PBS at room temperature for $1 \mathrm{~h}$. The membrane then was incubated with rabbit polyclonal anti-Fib antibody (1/3000) (H-140, Santa Cruz Biotechnology, Dallas, TX, USA), for $1 \mathrm{~h}$ at room temperature and with the IRDye ${ }^{\circledR} 800 \mathrm{CW}$ goat anti-rabbit IgG secondary antibody from LICOR for $1 \mathrm{~h}$ at room temperature, with three washes of $10 \mathrm{~min}$ each with PBS-T between incubations. Immunoblotting signals were analyzed by Odyssey Infrared Imager 9120 (LI-COR Biosciences, Lincoln, NE, USA). For small peptides, the primary antibody was anti-6xHis (1/5000) (Abcam, ab18184, mouse monoclonal) and IRDye ${ }^{\circledR} 800 \mathrm{CW}$ goat anti-mouse IgG secondary antibody.

\subsection{Fibrillarin Mutagenesis}

Mutagenesis of the fibrillarin sequence was performed with the Thermo Scientific Phusion Site-Directed Mutagenesis Kit, using specific primers for each mutation: fwd 5'-TTTGGCGGGGGCGCGGGTCGAGGCGGA-3', rev 5'-GCCCCCTCGGCCTCCACGAC-3' and 5'-AGGTCGTGGAGCGGGAGGAGGTG-3' , rev 5'-CTAAAGCCTCCGCCTCGACC-3' for R34A and R45A mutant, respectively.

\subsection{RNA In Vitro Transcription}

T7 RNA polymerase was used to in vitro transcribe on sense the U3 snoRNA cloned into the pGEM T-easy vector and SP6 RNA polymerase in antisense (New England BioLabs, Ipswich, MA, USA).

\subsection{RNA Extraction from HeLa Human Cells}

Total rRNA was extracted from the HeLa cell culture using a commercial kit, GenElute ${ }^{\mathrm{TM}}$ Mammalian Total RNA Miniprep (Sigma-Aldrich, St. Louis, MO, USA).

\subsection{In-Gel RNAse Activity Assay}

Measurements were performed as zymography. Protein samples were separated in 15\% SDS-PAGE gel. Resolving gel was supplied with $5 \mathrm{mg} / \mathrm{mL}$ of total extracted HeLa RNA prior to polymerization. After electrophoresis, the gel was washed for $10 \mathrm{~min}$ with buffer I (10 $\mathrm{mM}$ Tris- $\mathrm{HCl}, 20 \%$ isopropanol, 
pH 7.5) and incubated for $30 \mathrm{~min}$ in buffer II (10 mM Tris-HCl, pH 7.5) and buffer III (100 mM Tris-HCl, $\mathrm{pH}$ 7.5). The gel was resolved with $0.2 \%$ of toluidine blue and washed with water until the activity band was visible [42].

\subsection{In Vitro RNA Activity Assay}

Total RNA extracts from HeLa cells were mixed with HeLa expressed and purified SNAP-tag-fibrillarin complexes with or without the GAR domain; alternatively, recombinant fibrillarin was used alone in RNAse activity buffer $(25 \mathrm{mM}$ Tris-HCl pH8, $100 \mathrm{mM} \mathrm{NaCl}, 0.1 \mathrm{mM}$ EDTA, 0.1 DTT, and glycerol $10 \%$ ) +0.8 to $1 \mathrm{U} / \mu \mathrm{L}$ of RNAse inhibitor (Thermo Fisher) and incubated for $45 \mathrm{~min}$ at $37^{\circ} \mathrm{C}$, then loaded in a $3 \%$ agarose gel. Phosphoinositides and PA were added to the final amount of $50 \mathrm{ng}$.

\subsection{Fat Blot Assay}

PIP strips were used for the fat blot assay (P-6001, Echelon ${ }^{\mathrm{TM}}$, Santa Clara, CA, USA). The assay was made according to the manufacturer's instructions with $0.4 \mu \mathrm{g}$ of protein.

\subsection{Fluorescence Recovery after Photobleaching}

FRAP experiments were performed on a DeltaVision OMX Super-resolution microscope. HeLa cells were transiently transfected with pGFP-FIB and mutant constructs for the live cell analysis. DMEM media was replaced with warm phosphate-buffered saline medium (Dulbecco, Darmstadt, Germany) before the experiment. Dishes were placed in a temperature-controlled chamber supplemented with $\mathrm{CO}_{2}$. Images were obtained with a CMOs camera, using the $60 \mathrm{X}$ oil 1.42 objective with fluorescence free immersion oil 518F. For each photobleaching assay, one Cajal Body (CB) or nucleolus (Nco) was selected per cell and stated as the region of interest (ROI). The ROI was selected manually for immediate lase photobleaching (single point FRAP), then the fluorescence recovery was monitored, each experiment lasting $120 \mathrm{~s}$, with one image acquired per second. Photobleaching removed $\sim 99 \%$ of total fluorescence in both the nucleolus and CB. Image processing was performed with ImageJ®software for half-life $\left(\tau_{1 / 2}\right)$ value extraction plus mobile and immobile fractions. $R$ software was used to carry out quantitative and statistical analysis. Estimation of the diffusion coefficients (D) of wild-type and mutants was carried out as described in [43]. Each mutant was compared to wild-type (WT) under independent measurements; therefore the $\mathrm{SD}$ in the graph for WT is $n=50$ for Nco and $n=50$ for CB compared to each mutant $n=25$ for Nco and CB, respectively.

\subsection{Bioinformatic Analysis}

Complete proteomes of 35 chordate species and Saccharomyces cerevisiae were used to retrieve GAR containing proteins. The complete list of species and their proteome files are listed in Table S1. To identity GAR containing proteins, hidden Markov models (HMM) were constructed and calibrated from the alignment of 250 sequences retrieved by PSI-Blast [44] against the Refseq-protein database. The fibrillarin (FIB; AAP36189.1) and $h$ GAR1 (Q9NY12.1) protein sequences from $H$. sapiens were used as queries against the Chordata organism database (taxid:7711). The complete list of retrieved fibrillarin proteins is shown in Table S2. An HMM model of the GAR domain was constructed from the alignment of the fibrillarin retrieved proteins and was subsequently used to detect other GAR domain-containing proteins in the 36 complete genomes. The list of retrieved proteins containing a GAR domain structure is given in Table S3.

\section{Results}

\subsection{Fibrillarin as a Ribonuclease}

Unlike other proteins studied in our laboratory, we unexpectedly detected RNA degradation activity during the process of recombinant fibrillarin purification. Therefore, this effect was studied 
more deeply to clarify whether recombinant fibrillarin was the cause of degradation or whether a ribonuclease interacted with the fibrillarin preparations. We purified recombinant fibrillarin to near homogeneity (Figure 1a) after several chromatographic steps, as stated above.

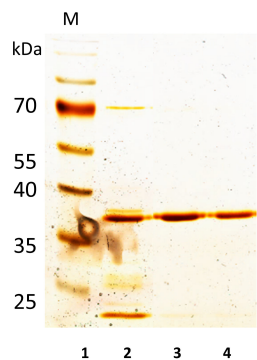

(a)

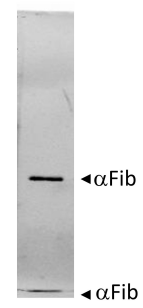

(b)

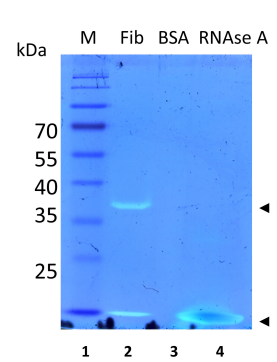

(c)

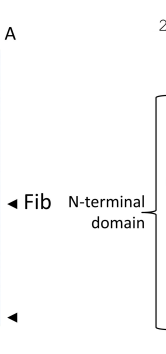

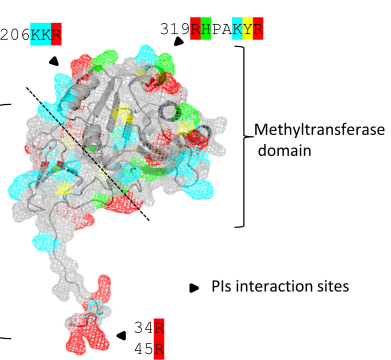

(d)

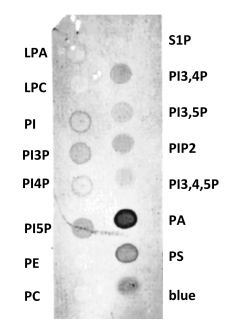

(e)

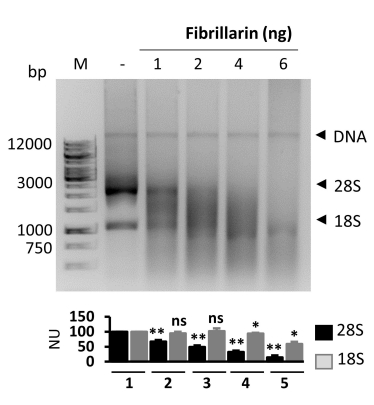

(f)

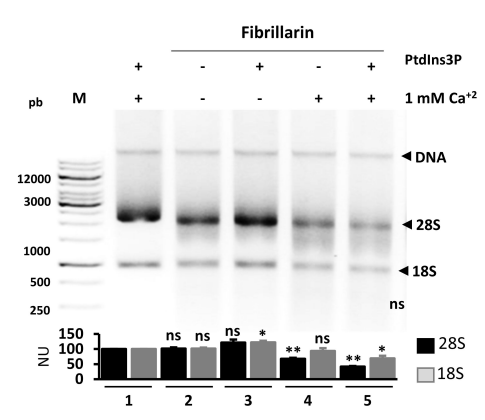

(g)

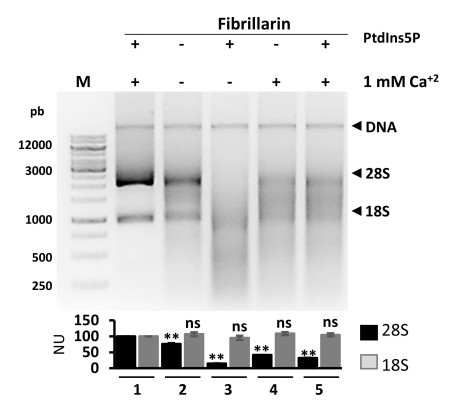

(h)

Figure 1. Fibrillarin acts as a ribonuclease. (a) Silver stain of purified fibrillarin. M: molecular weight marker. 2, 3, and 4: different fibrillarin elution profiles. Only elution 2 and 3 (major quality of protein purification) were used for further analysis. (b) Fibrillarin Western blot revealed two bands marked with arrow-heads that were recognized by specific fibrillarin antibody. (c) In-gel fibrillarin RNA assay shows two signals marked with arrowheads corresponding to fibrillarin (Lane 2). BSA and RNAse A were used as negative and positive controls, respectively (Lanes 3 and 4). (d) Computational inference of possible binding sites for phosphoinositides, one residing in the GAR domain and two in the globular C-terminal domain, are marked with arrows. The fibrillarin sequence with characteristic amino acids for phosphoinositide-binding is noted. Three to five amino acids are necessary for phophoinositide-binding $[45,46]$. These amino acids should be positively charged with at least one having an aromatic ring. Red: arginine, blue: lysine, green: histidine, yellow: tyrosine. (e) Fibrillarin fat blot assay shows that fibrillarin interacts modestly with several phosphoinositides and strongly with PA. Figure S1 depicts the quantification signals made by ImageJ software. (f) Total RNA in vitro assay was performed while increasing the concentration of protein (from 2 to $8 \mathrm{ng}$ ) added to a constant concentration of rRNA $(2 \mu \mathrm{g})$. Degradation of RNA is directly proportional to the amount of fibrillarin. Copurified DNA from TriZol extraction is indicated by head arrows; the rRNA populations, i.e., $28 \mathrm{~S}$ and 18S, are indicated. Influence of PI3P (g) and PIP5 (h) on human fibrillarin in vitro ribonuclease assay. (f-h) Quantification of $28 \mathrm{~S}$ and $18 \mathrm{~S}$ signals were made by ImageJ software and represented in normalized units (NU), statistical significance was determined by $t$-test ( ${ }^{*} p$-value $<0.05 ;{ }^{* *} p$-value $<0.01 ; * * *$-value $<0.001, \mathrm{~ns}=$ not significant $p$-value $\left.>0.05\right)$ and plots are indicated below the gels from $n=3$.

Fibrillarin identity was verified Western blotting using an anti-Fib primary antibody (Figure 1b), and two bands were detected. The upper band corresponds to the expected size of full-length fibrillarin, whereas a lower molecular weight band may correspond to the degradation product of the main protein. An in-gel activity assay was used to confirm that the ribonuclease activity was from the purified fibrillarin (Figure 1c). One band coincided with the full-length of fibrillarin confirmed by Western blot (Figure 1b,c, Lane 2). In gel zymography, a small size band also exhibiting ribonuclease activity was 
noted (Figure 1c, Lane 2). This band corresponded with the potential fibrillarin degradation product detected by Western blot using an anti-Fib primary antibody (Figure 1b). Therefore, ribonuclease activity may be modular and present in a particular domain inside the fibrillarin sequence.

The interaction between fibrillarin and PIP2 has been reported [25]. Furthermore, according to the molecular characteristics for phosphoinositide binding [45,46], fibrillarin has the necessary amino acids (negatively charged and with aromatic rings) to bind phosphoinositides (Figure 1d). And indeed, in a phospholipid strip assay, fibrillarin interacted with phosphoinositides, but more strongly with the negatively charged PA (Figure 1e). From the homogeneous fibrillarin preparations, a dose-dependent ribonuclease activity in vitro assay was carried out by increasing the protein concentration from 1 to $6 \mathrm{ng}$ with a constant amount of $2 \mu \mathrm{g}$ of rRNA. The major 28/18S rRNA populations and their integrity used for the assay are depicted in Figure 1f Lane 2, and a DNA band co-purificated by TriZolßprotocol is marked with arrowheads. rRNA degradation was directly proportional to the amount of fibrillarin added (Figure 1f, Lanes 2 to Lane 5); 28S rRNA was affected but not $5 \mathrm{~S}$ rRNA (data not shown). The ribonuclease activity of fibrillarin was also found to be dependent on temperature, time, and display ion sensitivity (Figure S2).

Calcium ions have been detected in the crystal structure of human fibrillarin [47], and other enzymes with ribonuclease activity are either dependent on [48,49] or inhibited by calcium [50]. Our previous work showed that the AtFib2 from A. thaliana is activated with a small amount of calcium in ribonuclease activity assays, but no effect was observed in the same context with AtFib1 enzyme [51].

Ribonuclease activity was tested with PIP5 and PIP3 phospholipids with and without $1 \mathrm{mM} \mathrm{Ca}^{+2}$. The experiments were carried out with a reduced amount of fibrillarin $(<1 \mathrm{ng})$ to observe the likely activation of the enzyme (Figure 1g,h). The addition of PI3P had an inhibitory effect for rRNA digestion (Figure 1g, Lane 3), whereas the addition of PI5P resulted in a dramatic increase of ribonuclease activation (Figure 1h, Lane 3). Of note, these phospholipids did not affect rRNA in the absence of fibrillarin. Thus, strikingly, PIP3 and PIP5 differently affected the ribonuclease activity of fibrillarin.

\subsection{Ribonuclease Activity of the Recombinant Ribonucleoparticle Complex Involving Fibrillarin}

Fibrillarin forms part of one of the main snoRNP complexes that modify rRNA during ribosomal RNA biogenesis; this complex guides the specific methylation site of about 100 residues in the rRNA. The complex consists of three other well-known proteins: Nop58, Nop56, 15.5K, and one snoRNA guide [52-55].

To examine the ability of fibrillarin to degrade rRNA in the RNP context, a construct [41] containing a truncated fibrillarin (from amino acid 82 to 321) with the GAR domain absent in the coding sequence was compared to full-length fibrillarin. The first purified complex with full-length fibrillarin was termed RNP, and the second purified complex with truncated fibrillarin was termed RNP $\triangle G A R$. The two versions of the RNP complex were visualized on SDS-PAGE (Figure 2a); a shift in the fibrillarin corresponding size was observed.

The ribonuclease activity of RNP and RNP $\otimes$ GAR complexes was tested in vitro using $2 \mu \mathrm{g}$ of total RNA (Figure 2b); the complex with full-length fibrillarin degraded RNA, whereas RNP $\otimes$ GAR showed no significant activity. The addition of $1 \mathrm{mM} \mathrm{Ca}^{2+}$ did not affect the ribonuclease activity of either complex (Figure 2c). Similar to the experiments with purified fibrillarin, the influence of phosphoinositides were evaluated at a final concentration of $5 \mathrm{ng}$, but no effect of PIP3 and PIP5 was observed (Figure S3). Alternatively, PIP2 inhibited the ribonuclease activity of the complex in a concentration-dependent manner (Figure 2d). We also checked by structured illumination microscopy (SIM) the localization of PIP2 and fibrillarin using a SNAP-tag-fibrillarin construct in a stable cell line, indicating that in the nucleoli, the majority of fibrillarin surrounded PIP2 in the DFC (Figure 2e) and that the ring-like structure involved a change of phase which lacks the lipidic environment outside the DFC. Fibrillarin ring structures are likely formed by the interaction of rRNA, non-coding RNA, and phospholipids. The ring-like structure has a diameter with an average of $488 \mathrm{~nm}(\mathrm{SD} \pm 7 \mathrm{~nm})$, with a PIP2 core of $188 \mathrm{~nm}(\mathrm{SD} \pm 3.6 \mathrm{~nm})$. An analysis of the ring-like structure and its comparison to other 
proteins can be found in Figure S4 to Figure S8. In conclusion, the ability of fibrillarin to interact with several phospholipids may provide different functions in different phases from FC to DFC.

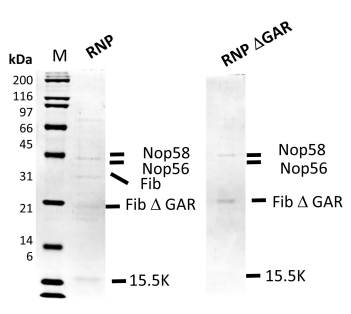

(a)

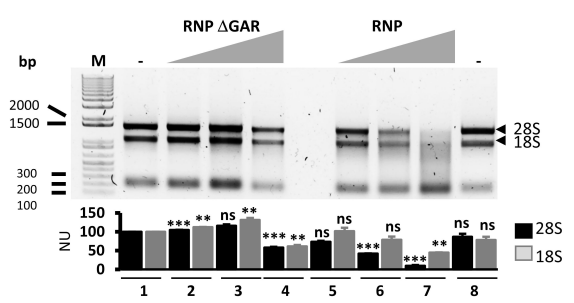

(b)

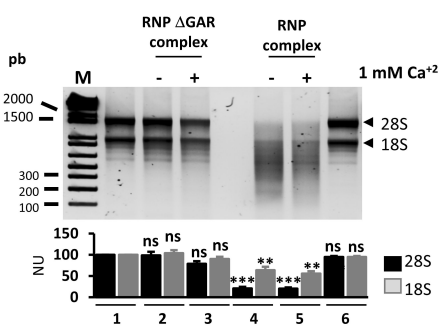

(c)

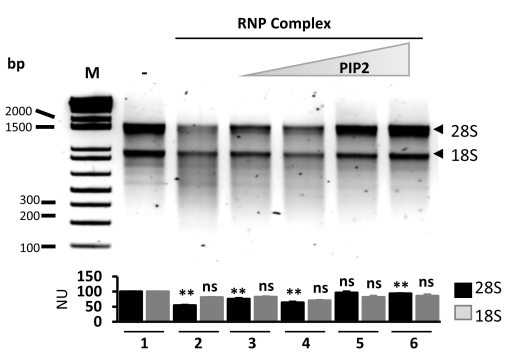

(d)
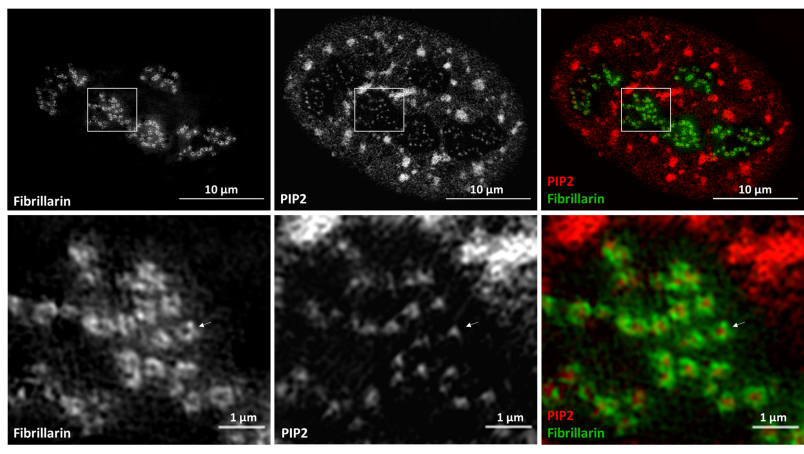

(e)

Figure 2. RNA activity of the recombinant ribonucleoprotein complex containing a truncated (RNP $\triangle \mathrm{GAR}$ ) and full-length complex (RNP). (a) IMAC affinity purification under native conditions of RNP $\triangle$ GAR and RNP complexes. The sequence coding GAR domain was inserted into the truncated fibrillarin-RNP complex, using the EMP-PCR strategy. A shift in the band size corresponding to fibrillarin is shown. The Nop58, Nop56, and $15.5 \mathrm{~K}$ proteins are copurified as expected and labeled in the figures in both RNP purifications (b) Comparative activity of complexes with or without GAR domains. No activity was detected using increasing amounts of native RNP $\triangle G A R$, while RNA degradation was observed with full-length fibrillarin in the complex. (c) Influence of calcium at $1 \mathrm{mM}$ on the RNA activity. No significant modification of activity was observed between the complexes. (d) In vitro RNA assay using increasing amounts of PIP2 lipid. Increasing amounts of phospholipid from 1 to $100 \mathrm{ng}$ inhibited the of RNA activity. (b-d) Quantification of $28 \mathrm{~S}$ and $18 \mathrm{~S}$ signals were made by ImageJ software and statistical significance was determined by $t$-test ${ }^{*} p$-value $<0.05 ;{ }^{* *} p$-value $<0.01$; $* * * p$-value $<0.001$, ns $=$ not significant $p$-value $>0.05$ ) and plots are indicated below the gels from $n=3$. (e) Colocalization of SNAP-tag-fibrillarin and immuno-labeled PIP2 (left panel) in HeLa cell nucleus. White inset is magnified in the right panel; the red signal corresponds to PIP2 and the green one to SNAP-tag-fibrillarin.

\subsection{Fibrillarin Specificity Ribonuclease Activity in Complex with RNA Guide}

The specificity of the SNAP-tag-fibrillarin complex as a ribonuclease was tested against U3 snoRNA, one of several RNA processing guidelines for rRNA that interacts with fibrillarin (Figure S9). Fibrillarin did not degrade U3 snoRNA, but interacted with it, resulting in retardation, as confirmed by GMSA (Figure 3a). The addition of PA dissociated the complex from U3 snoRNA (Figure 3a), whereas PIP2, under the same conditions, showed a minor alteration in the complex migration on gel (Figure 3a, Lanes 3 and 5). 


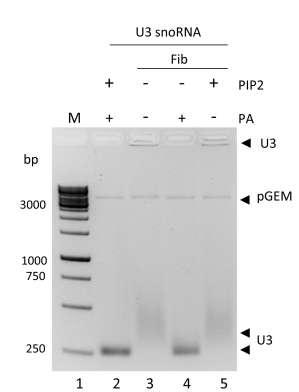

(a)
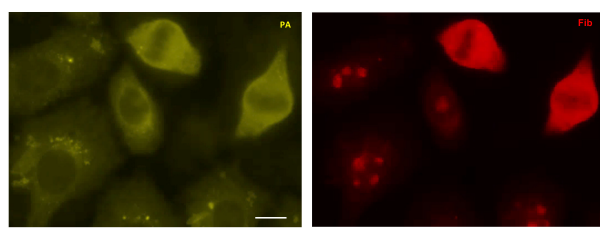

(e)

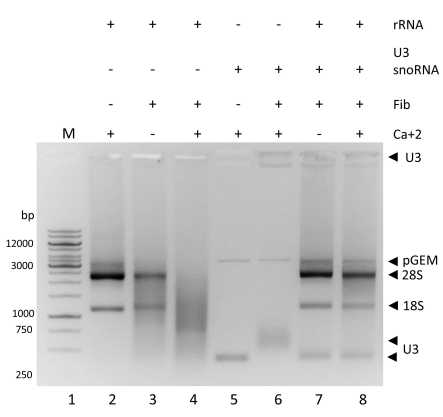

(b)

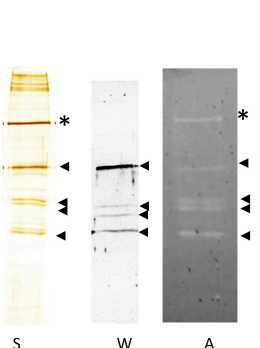

(c)

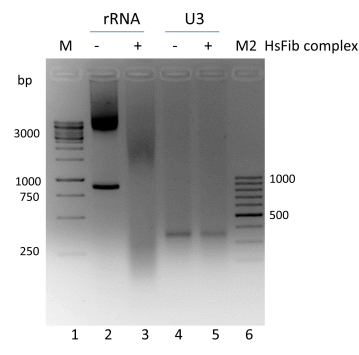

(d)

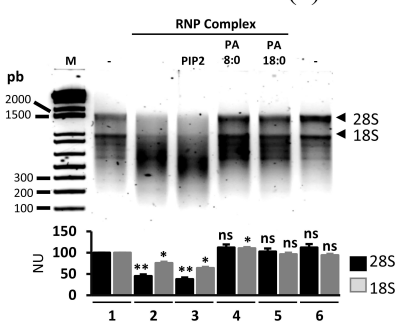

(f)

Figure 3. RNA specific RNA activity by fibrillarin with snoRNA U3. (a) Gel shift of snoRNA U3 with WT fibrillarin. All incubations and procedures carried out at $4{ }^{\circ} \mathrm{C}$, PIP2 and PA were added as indicated. Plasmid control pGEM was used to normalize each lane. (b) RNA activity of fibrillarin with or without guide snoRNA U3 added. Reactions were carried out at $37^{\circ} \mathrm{C}$. (c) In-gel RNA activity of native fibrillarin RNP complex, labeled with silver staining (S), revealed by Western blot (W) and tested by activity assay (A). Arrowheads indicate fibrillarin and potential degradation products, and an asterisk indicates an undetermined ribonuclease activity (d) In vitro RNA activity of HeLa expressed and purified SNAP-tag-fibrillarin complex against total RNA and snoRNA U3. (e) Immunofluorescence showing the colocalization of PA and fibrillarin. The signal corresponds as follows: Blue-DAPI (nucleus signal), Yellow-PA sensor, and RED-fibrillarin. (f) In vitro RNA assay using PA. An inhibition effect was observed using PA containing 8 or 18 carbons and no saturation in the lateral chains (8:0 or 18:0), whereas little effect on the activity was observed with PIP2. Quantification of $28 \mathrm{~S}$ and $18 \mathrm{~S}$ signals were made by Image J software and statistical significance was determined by $t$-test $\left({ }^{*} p\right.$-value $<0.05$; ** $p$-value $<0.01 ; * * *$-value $<0.001$, ns $=$ not significant $p$-value $>0.05)$ and plots are indicated below the gels from $n=3$.

Fibrillarin was not able to degrade rRNA when pre-incubated with snoRNA U3 for 15 minutes, prior to rRNA addition, suggesting that U3 snoRNA blocked the ribonuclease activity of fibrillarin (Figure 3b, Lane 7). When fibrillarin was incubated for 15 minutes without U3 snoRNA followed by the addition of rRNA, degradation was observed as expected. HeLa expressed and purified SNAP-tag-fibrillarin complex also showed ribonuclease activity (Figure 3c). An in-gel activity assay of the HeLa purified fibrillarin complex had 5 bands with ribonuclease activity corresponding to four bands revealed by Western blotting with anti-fibrillarin antibody (Figure 3c; marked with arrowheads). Fibrillarin degradation is likely to have occurred during the complex purification, as fibrillarin is prone to degradation even in the presence of protease inhibitors. The fifth band (asterisk) showed as-yet-undetermined ribonuclease activity. Fibrillarin complex from HeLa cells was unable to cut snoRNA U3 (Figure 3d). The subcellular distribution of PA was determined using a PA sensor described previously [39]. In HeLa cells during interphase, on one side, fibrillarin is concentrated in the nucleolus and, on the other side, the majority of a PA sensor was detected in perinuclear structures reminiscent of the Golgi apparatus with very little overlap of the signals (Figure 3a). Upon nuclear membrane rupture during mitosis, fibrillarin is abundantly relocated to the cytoplasm, where it colocalized with the PA sensor, as shown in Figure 3e. Note that during mitosis, the vesicular distribution of the PA sensor completely disappears. It is thus possible that fibrillarin interacts with PA in the cytoplasm during 
mitosis. The presence of PA inhibited the in vitro activity of the full-length fibrillarin containing the recombinant complex. This inhibition was not dependent on the size of the acyl chains of PA (Figure 3f, Lanes 4 and 5). A small change in the digestion pattern was, however, observed with low amounts of PIP2 (Figure 3f, Lane 3).

\subsection{GAR Domain, Modular in Fibrillarin}

Next, we evaluated the ability of the GAR domain from the recombinant complex to act as an active domain. The N-terminal region (GB: 1-134 aa) of fibrillarin includes the GAR domain and a sequence of amino acids 58 to 136 (the BCO) that has no defined function [10]. The GB (GAR and BCO regions) domain was cut into several sections, as depicted in Figure 4a. Constructs fused to GST and 6xHis were expressed and purified by a double-step purification and detected by a specific antibody (Figure $4 \mathrm{~b}, \mathrm{c}$ ). The GAR domain exhibited ribonuclease activity, whereas the BCO did not show any activity (Figure 4d, Lane 5). Further deletions of amino acids 1 to 20 and 13 to 68 of the GAR domain abolished activity (Figure 4d, Lanes 4 and 6, respectively).

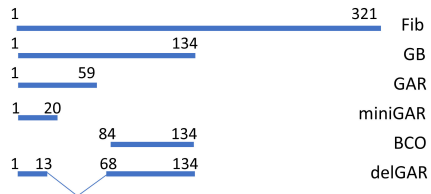

(a)

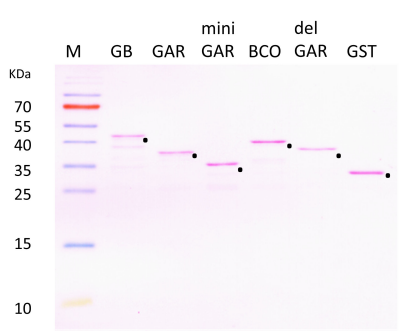

(b)

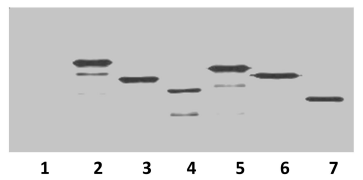

(c)
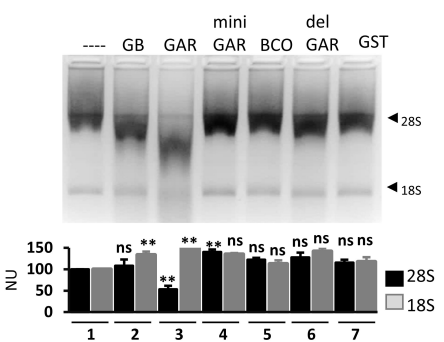

(d)

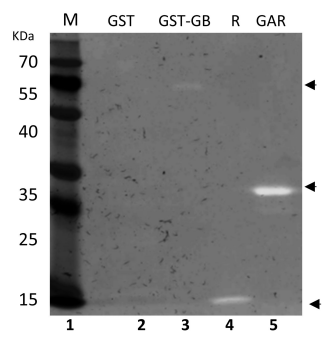

(e)

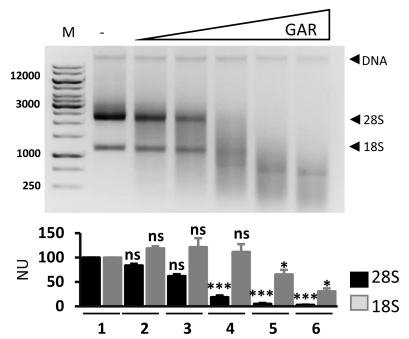

(f)

Figure 4. The GAR domain of fibrillarin is a modular domain with RNA activity. (a) Schematic representation of small peptides expressed from GB. (b) Ponceau staining of the HsGB small peptides expressed. All peptides were fused to the GST and 6 His tags. The band corresponding to the expected peptide is shown by a dot. (c) Anti-6xHis antibody was used to identify each peptide by Western blot. (d) RNA assay from the purified peptides. Under the same conditions, the GST-GAR domain has higher activity than the GST-GB domain (Lanes 2 and 3). The other peptides (miniGAR, BCO, and delGAR) have no activity. GST was used as a negative control. (e) In-gel RNAse assay of fibrillarin GB domain (amino acids 1 to 134). Degradation of RNA is higher when GST was cleaved from the GAR domain (Lanes 3 and 5). GST and RNAse A (R) were used as negative and positive controls, respectively. (f) RNA activity assay of the GAR domain. rRNA degradation is directly proportional to the amount of the GAR domain. (d,f) Quantification of $28 \mathrm{~S}$ and $18 \mathrm{~S}$ signals were made by ImageJ software and statistical significance was determined by $t$-test $\left({ }^{*} p\right.$-value $<0.05 ;{ }^{* *} p$-value $<0.01 ;{ }^{* * *} p$-value $<0.001$, ns $=$ not significant $p$-value $>0.05$ ) and plots are indicated below the gels from $n=3$.

An in-gel ribonuclease activity assay showed that the GAR domain fused with GST degraded RNA, and its activity increased when GST was cleaved (Figure 4e, Lanes 3 and 5). Increasing concentrations of purified GAR domain caused significant degradation of rRNA at the highest amount tested. Interestingly, $28 \mathrm{~S}$ rRNA was the first target for the degradation using this domain (Figure 4f). 


\subsection{Mutation of the GAR Domain}

From sequence analysis of the GAR domain, the conserved arginine in position 34 and 45 was chosen to be substituted with alanine (Figure 5a). Presumably, the alteration of amino acids causes a conformational change that better exposes the GAR domain in the R45A mutant, but not in R34A. The amount of all pure recombinant fibrillarins was normalized for ribonuclease activity or phospholipid-binding assays (Figure $5 \mathrm{~b}, \mathrm{c}$ ). Surprisingly, R34A and R45A fibrillarin mutants lost the ability to interact only with the PIP2, PA, and phosphatidylserine (PS), while interaction with PI3P and PI5P remained. R34A mutant also interacted weakly with phosphatidylcholine (PC) and sphingosine-1-phosphate (S1P) (Figure 5c). In conclusion, both mutations affected interaction with several anionic phospholipids, as shown by fat blot analysis, in agreement with the model where the positive arginine charges are essential for anionic phospholipid binding. WT fibrillarin and the R34A fibrillarin mutant degraded the rRNA $28 \mathrm{~S}$ to the same degree, but the R45A fibrillarin mutant was found to be more active and degraded up to $80 \%$ of $28 \mathrm{~S}$ rRNA (Figure $5 \mathrm{~d}$ ).

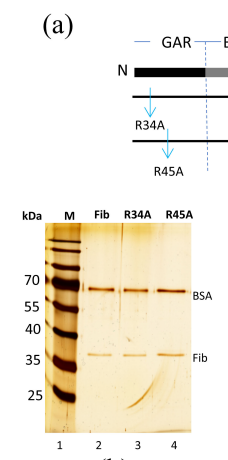

${ }^{2}(\mathrm{~b})^{3}$

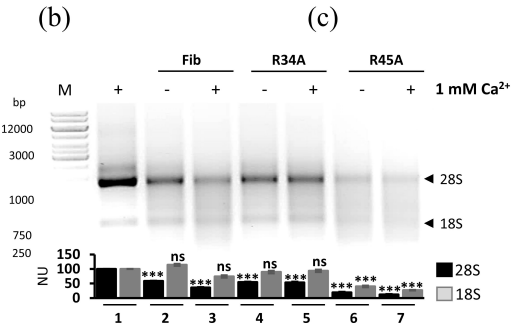

(d) (e)
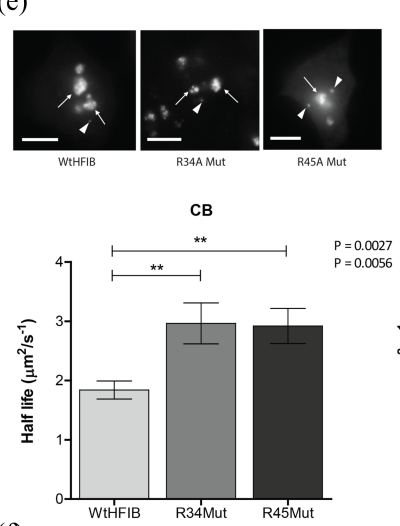

(f)

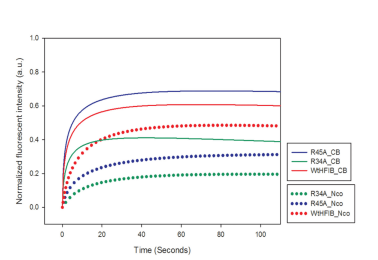

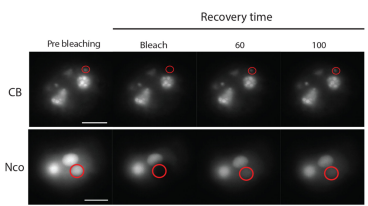

Nco
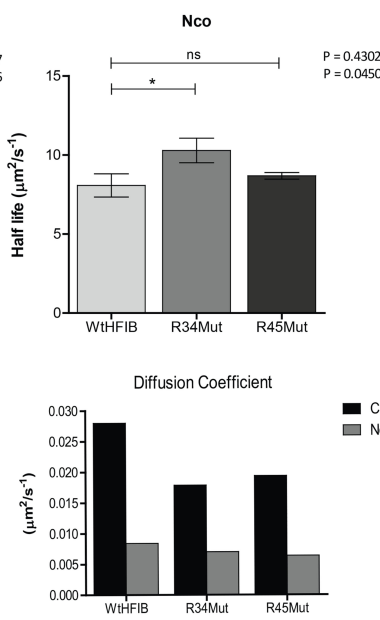

Figure 5. Activity of GAR domain mutants. (a) Schematic representation of fibrillarin domains GAR, $\mathrm{BCO}$, and RNA binding alpha-helix domain. Blue arrows represent mutations R34A and R45A in the fibrillarin GAR domain. (b) Silver stain normalization of WT, R34A, and R45A fibrillarin. (c) Fat blot assay for fibrillarin mutants R34A and R45A. Figure S1 depicts the quantification signals made by ImageJ software. (d) RNA activity of fibrillarin mutants R34A and R45A. Quantification of 28S and $18 \mathrm{~S}$ signals were made by ImageJ software and statistical significance was determined by $t$-test ( ${ }^{*} p$-value $<0.05 ;{ }^{* *} p$-value $<0.01 ;{ }^{* * *} p$-value $<0.001, \mathrm{~ns}=$ not significant $p$-value $>0.05$ ) and plots are indicated below the gels from $n=3$. (e) Transiently transfected HeLa cells expressing GFP-WT-fibrillarin, R34A, or R45A mutant coupled to GFP. In the upper left panel, representative images of the conventional localization of human fibrillarin in nucleoli (arrows) and Cajal bodies (arrowheads) are shown for WT and mutants. Intranuclear localization for WT fibrillarin and its mutants was observed in live cells. On the upper right panel, one representative photobleaching experiment is shown for a Cajal body and, for a nucleolus, red circles delimit the ROI, which was subsequently photobleached. The lower graphs plot the half-life coefficients obtained from 200 independent FRAP experiments comparing WT and mutants fibrillarins in CBs and NCOs; error bars correspond to SEM. (f) The left graph represents the normalized dynamics from 200 independent photobleaching events for WT and mutant fibrillarins in CBs and NCOs; the curves in the graphs represent the normalized values of the mean $(n=200)$ for each condition for each time point. The bar graph on the left shows a resume of the single diffusion coefficient values obtained from the previous analysis. 
WT fibrillarin, mutant R34A, or R45A genes fused to GFP showed the previously reported intranuclear localization (enrichment in nucleoli and Cajal bodies) [1,2], but different intranuclear behavior in transiently transfected in HeLa cells. FRAP analysis showed that fibrillarin mutants had a $40 \%$ lower diffusion coefficient in Cajal bodies (CBs) showing statistical difference in $p$-values CB (WT R34) $\left.p=0.0056{ }^{(* *}\right)$, and (WT - R45) $p=0.0027\left(^{* *}\right)$. The mutants showed minor reduction in mobility in the nucleus (Nco) with $p$-values for Nco (WT - R34) $p=0.0450{ }^{*}$ ) and for (WT - R45) $p=0.4302$ (ns). Nucleolar R34A and R45A fibrillarin mutants showed a significant diminution in dynamic speed compared to WT, as reflected in increased half-lives. Compared to WT fibrillarin, R45A had a 50\% reduction in nucleoli size, of which the intranuclear localization is shown in Figure 5e. In CBs, there was also an increase in the half-lives of R45A and R34A versus WT fibrillarin, reflected in smaller diffusion coefficient values observed as the longer residence time of the mutants within the nucleolus and CBs in comparison with WT (Figure 5f).

\subsection{Ribonuclease Activity of GAR-Like Domains Containing Proteins}

The phylogenetic tree constructed from the alignment of the GAR domain of the retrieved fibrillarin proteins was grouped into 3 major clades (Figure 6a; protocol and data in Figure S10). The basal branch contained the GAR domain of NOP1 protein from S. cerevisiae, the most ancestral species analyzed, and sequences of non-mammalian species. Group A was divided into 2 subclades (A1 and A2) and contained nearly all vertebrate species with single fibrillarin sequences. Group A contained mammalian sequences only, as compared to the basal group. Subgroup A1 contained GAR sequences from non-primates except for the Gorilla GAR sequence. Species with a second fibrillarin sequence were clustered in group B and exhibited a distinctive GAR pattern (Figure S11).

Using the HMM model constructed from the GAR domain of fibrillarin proteins, five different protein classes were retrieved: the fibrillarin proteins (fibrillarin domain), LSM14-A proteins (containing LSM14 (Scd6-like Sm domain and FDF domain), a predicted autoimmune regulator in armadillo (Dasypus novemcinctus, containing HSR domain and PHD-finger), a predicted nucleolin isoform in rabbit (Oryctolagus cuniculus, containing 4 repeats of RRM1 (RNA recognition motif, RRM, RBD, or RNP domain), a nucleolar RNA helicase 2 in Zebrafish (Danio rerio, containing a DEAD (DEAD/DEAH box helicase), and a Helicase C (Helicase conserved C-terminal domain) and a GUCT (NUC152) domain). All 5 retrieved proteins contain domain regions with repeats of glycine-arginine amino acids known as RGG boxes, which are present in several proteins that participate in transcription, RNA binding and splicing and protein interactions [56-58]. A representation of the GAR domain location in each of the 5 retrieved proteins is depicted in Figure 6b. HMM for RGG-box 1 and RGG-box 2 repeats from GAR1 proteins were constructed, and other GAR1 proteins were detected in the analyzed genomes (Figure S12). LMS14-A was detected in 20 different species and contained 2 different R/G boxes, one before the FDF domain (a 20 aa R/G box I) and the other after the FDF domain (a 44 aa R/G box II). A multiple-sequence alignment of 23 LSM14-A proteins was performed and visualized with the Boxshade tool available at https://embnet.vital-it.ch/software/BOX_doc.html. The structure of the $\mathrm{R} / \mathrm{G}$ rich region in such proteins followed the characteristic motif of the GAR domain (Figure S13). Considering that the GAR domain is absent in Archaebacteria fibrillarins and that it acts as a modular domain in other proteins, the published genomes for similar sequences were revised.

The Barley Stripe Mosaic Virus (BSMV) Triple Gene Block1 (TGB1) is a 58 kDa movement protein that possesses RNA-binding, RNA helicase, and ATPase activities [59-61]. The BSMV TGB1 protein contains a nuclear localization signal (NLS) and a nucleolar localization signal (NoLS) between 227-238 and 95-104 amino acids, respectively. BSMV TGB1 protein interacts with the GAR domain of the nucleolar fibrillarin (Fib2) from Nicotiana benthamiana [62]. Other examples correspond to the ORF3 viral protein that also interacts with the fibrillarin GAR domain [63]. Some NLS and NoLS contain intrinsically disordered regions $[64,65]$ that help direct viral proteins to the nucleolus during viral infection. Therefore, the potential for TGB1 to degrade RNA was evaluated. 


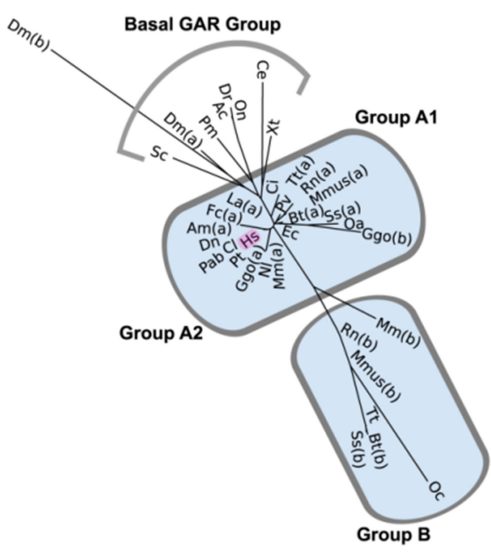

(a)

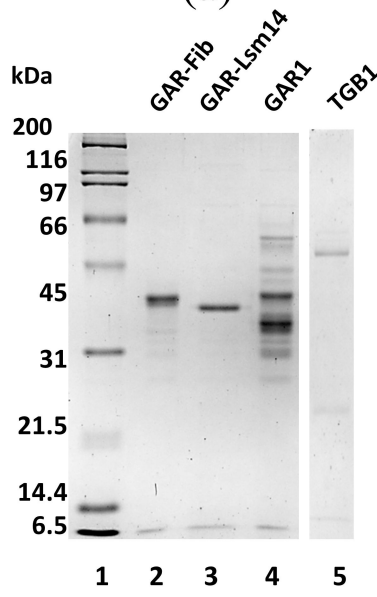

(c)

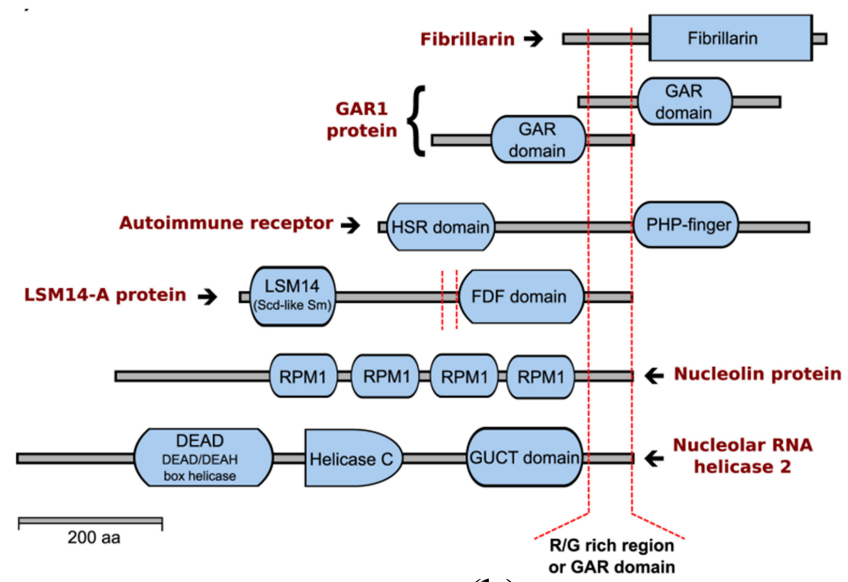

(b)

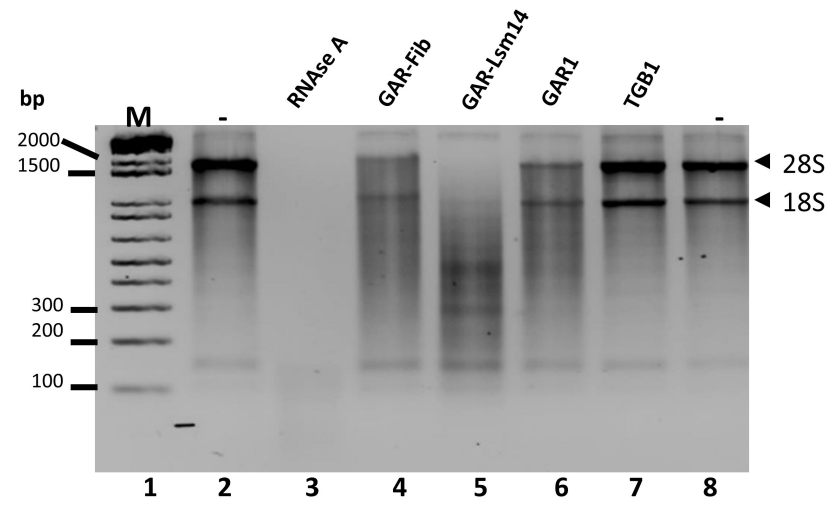

(d)

Figure 6. RNA activity of GAR domains from different RNA-binding proteins. (a) Bioinformatic analysis of $R / G$ rich region (or GAR domain) of retrieved proteins from 36 complete genomes. The phylogenetic tree of GAR domains of fibrillarin proteins was retrieved from chordates genome data. GAR domains were clustered in three major clades: A, B, and the basal group. Clade A was divided into A1 and A2 subgroups. (b) Schematic representation of different modular proteins shows the presence of GAR domains in N- or C-terminal regions. Five proteins contained GAR domains similar to fibrillarin: GAR1 protein, an autoimmune receptor, Lsm14, Nucleolin, and a nucleolar RNA helicase 2. (c) IMAC affinity purification of GAR domains from fibrillarin, Lsm14, GAR1, and viral protein TGB1 with a disordered domain similar to GAR. (d) In vitro RNA assay of four GAR domains expressed and purified from E. coli. TGB1 and GAR1 (Lanes 6 and 7) showed no activity against total RNA. RNAse A diluted 1:20,000 was used as control.

Cloning and expression in E. coli were performed for the GAR domains from Lsm14, full-length GAR1, and the viral protein TGB1, before IMAC purification (Figure 6c), and their ribonuclease activity was compared in vitro with that of the GAR domain of fibrillarin. As shown in Figure $6 \mathrm{~d}$, the GAR domains from fibrillarin, LMS14, and GAR1 presented different degrees of activity as compared to the activity of RNAse A (Lane 3), which degraded total rRNA. In contrast, GARs from fibrillarin (Lane 4), Lsm14 (Lane 5), and GAR1 (Lane 6) presented a different pattern of degradation and null activity, as in the case of TGB1. Thus, not all the intrinsically disordered regions presented activities related to rRNA processing (Lane 7). We hypothesized that glycine-arginine repeat domains raised during evolution as a part of the lipid complexity and functional compartmentalization are required in the nuclear environment. 


\section{Discussion}

Fibrillarin is an essential protein whose function and structure are highly conserved in all eukaryotic organisms $[10,66]$. It functions as a methyltransferase involved in the processing of rRNA [67] and the methylation of histone H2A in RNA Pol I promoters [12,13]. Here we describe its activity as a ribonuclease even in the absence of a complex with Nop56, Nop58, and 15.5K proteins. Ribosomal biogenesis requires strict control and tight regulation to maintain a high order of rRNA production $[68,69]$. The $47 \mathrm{~S}$ pre-rRNA transcribed binds co-transcriptionally to fibrillarin in the periphery of the FC/DFC in its 5' end, and the self-assembly of fibrillarin in its GAR domain facilitates a directional sense of the pre-rRNA processing [70], forming specific clusters of RNA-protein complexes that mediate subsequent modifications of pre-rRNA after transcription. The ring-like structures are highly ordered and may involve a phase separation for fibrillarin activity. RNA pol I, together with UBF, are localized in the center with the majority of the nucleolar PIP2 pool. The majority of fibrillarin is found in this surrounding area, as seen in Figure 2e. The particular ring structures are similar in size and shape to those previously identified by labeling SLERT. The RNA SLERT is known to associate and regulate pre-rRNA transcription and rRNA production, leading to increased tumorigenesis [71].

The initial possibility for ribonuclease activity of fibrillarin was suggested by Kass et al. [18], who determined that a ribonucleoprotein complex containing fibrillarin and snoRNA U3 was involved in specific ribonuclease activity, using nuclear extracts from mouse cells. Furthermore, an antibody against fibrillarin decreased rRNA digestion significantly [18]. Tollervey and collaborators [67], using NOP1 (yeast fibrillarin), showed that its depletion reduced the level of mature rRNA but increased the amount of uncut premature rRNA [72]. In cruciferous plants, Vasquez-Saez et al. [22] isolated the ribonucleoprotein complex nuclear factor D consisting of 30 proteins, including fibrillarin, nucleolin, and the snoRNAs U3 and U14. The complex can interact with rDNA and cut into the P site, downstream from the A1, A2, A3, and B sequences located in the 5' ETS of pre-rRNA. However, the ribonuclease activity was not associated with any particular protein. In C. elegans, fibrillarin is a key regulator of pathogen resistance during bacterial pathogen infection [73]. In vitro and biomolecular fluorescence complementation assays [74] showed in A. thaliana that fibrillarin (FIB2 gene) can interact with the ELF18-INDUCED LONG NONCODING RNA 1 (ELENA1) lncRNA and directly with MED19a in the nucleoplasm and the nucleolus, demonstrating that the FIB2 gene is a negative transcriptional regulator of immune responsive genes like PR1. We found here that the GAR domain of fibrillarin is responsible for its activity as a ribonuclease. The GAR domain is present in several nucleolar proteins, i.e., nucleolin [75], NSR1 [76], SSB1 [77], and GAR1 protein [78], which have RNA recognition motifs like fibrillarin, directly interact with rRNA, and are involved in its processing [78,79]. In fibrillarin, the GAR domain is needed to target nucleoli [80] and for interaction with nuclear phase viruses [63].

There is an increasing suggestion about how LLPSs are regulated in relation to the post-translational modifications (PTMs) on the disordered domains of different nucleolar proteins that promote phase separation behavior. Cross-talk between PTMs such as phosphorylation and methylation regulates and affects interactions between protein partners or other molecules. NOP1, the fibrillarin yeast counterpart, can be methylated at six of nine SRGG motifs, which belong to the GAR domain, and this arginine methylation increases the ability of NOP1 to interact with the major RNP proteins Nop56 and Nop58, also regulating the localization of NOP1 during ribosomal processing [24]. The mutations we carried on two arginines in fibrillarin led to an alteration in nucleolar size and dynamics associated with an alteration to phosphoinositide binding.

Furthermore, we established the interaction of various phospholipids with fibrillarin, including phosphoinositides and PA. Within the cell nucleus, phosphoinositides are essential cofactors for various processes ranging from transcription regulation and differentiation to cell cycle control $[28,81]$. Previously we described that PIP2 interacts with fibrillarin affecting its RNA binding mobility in native PAGE [25]. Here we also show that fibrillarin also interacts with PA. The general ribonuclease activity decreases upon interaction with PA and releases fibrillarin from the interaction with the guide snoRNA 
U3. We suggest that during mitosis, the interactions between PA and fibrillarin may prevent unspecific degradation of RNA and allow different complex formation.

Negatively charged phospholipid-binding domains usually require positive charges. A clear example is the $\gamma$-core, where the arginine has been mutated in a signature similar to that of the GAR domain of fibrillarin. Such mutations show similar alteration of phosphoinositide binding [82] as in our mutants. The mutation made in the GAR domain of R45A has a more significant effect on the activity of fibrillarin as a ribonuclease. Both mutants (R34A and R45A) modify the interaction with negatively charged phospholipids compared to WT fibrillarin. Phospholipids affect binding to proteins and can promote protein-protein interaction. An example is the PDZ domain (PSD-95/Discs large/ZO-1) of syntenin-2 [83]. This domain interacts with PIP2, regulating the nuclear organization of some proteins bearing this domain. The mutants for this PDZ domain (in positions Lys113, Lys167, Lys197, and Lys244) result in a loss of binding with PIP2 and functional alteration [83]. The nucleolar size changes in mutants may result from changes in protein interactions, as indicated by our FRAP experiments. Since fibrillarin interacts with at least 235 proteins [10], the mutations may lead to a reduction in size due to improper complex formation, resulting in a partial compromise in nucleoli architecture.

Ribosome biogenesis is an essential cellular process that consumes cell energy [84]. During interphase, where a high degree of ribosome synthesis is required, fibrillarin is mostly deacetylated by the NAD+ dependent deacetylase SIRT7, increasing H2AQ104 methylation levels and ensuring rRNA synthesis by Pol I complex activity. Here we show that fibrillarin also acts as a ribonuclease regulated by phosphoinositides and PA. It is favorable for the cell to inhibit a ribonuclease like fibrillarin during metaphase, and PA may provide such a mechanism. The PA found in membranes in the cytosol may interact with fibrillarin once the nuclear membrane is broken during metaphase. However, clearly more research in the subject is needed before this could be concluded. Fibrillarin ribonuclease activity may be directed by some guide RNA, like snoRNA U3, together with a phase change for functional localization. We used a complete processed rRNA without the external and internal transcription spaces, in which U3 was involved to guide the cleavages in at least three different positions [18]. This is the reason why the complex fibrillarin-U3 snoRNA was not able to degrade rRNA. Yeast mutants of NOP1 show different phenotypes that affect ribosome function and rRNA biogenesis at different stages, including a lack of cleavage of the pre-rRNA. Here we show for the first time that human fibrillarin has a second activity that is essential for such processes $[10,51]$.

Supplementary Materials: The following are available online at http://www.mdpi.com/2073-4409/9/5/1143/s1, Figure S1: Quantification of Fat blot signals, Figure S2: Evaluation of the ribonuclease activity of fibrillarin, Figure S3: Ribonuclease activity assay of fibrillarin in the RNP complex or fibrillarin alone in the presence of different phosphoinositides, Figure S4: SIM image of SNAP FIB and Immunolocalize PIP2, Figure S5: SIM images taken along Z stack with $0.125 \mu \mathrm{M}$, Figure S6: Co-localization of GFP and SNAP tagged Fibrillarin, Figure S7: o-localization of immunolocalization fibrillarin and SNAP tagged Fibrillarin, Figure S8: SIM images of Snap-Fibrillarin, PA andPI4P during interphase, Figure S9: GMSA of fibrillarin in complex with snoRNA guides, Figure S10: Flow diagram of sequences analyzed by bioinformatics tools, Figure S11: GAR domain amino acid alignment, Figure S12: Phylogenetic analysis of the GAR domain branches founded in the proteomes of different species, Figure S13: Boxshade of the Lms14-A protein sequences. Table S1: List of chordate species and thier proteome files used in the analyses of GAR domain (Fibrillarin and GAR1 proteins), Table S2: Table. List of fibrillarin protein sequeces retrieved from 36 complete genomes of vertebrate species and a yaest (S. cerevisiae), Table S3: List of sequence proteins containing a GAR domain structure, retrieved from 36 complete genomes species by a HMM model from the GAR domain of FIB proteins.

Author Contributions: F.G.-C., U.R.C., and E.C. conceived the project and designed experimental strategies. F.G.-C. and U.R.C. performed the experiments. A.P.-S. performed the bioinformatic analysis. A.B. and L.Š. performed the imaging and confocal microscopy. C.A. performed the FRAP analysis. F.G.-C. and U.R.C. wrote the manuscript. E.C., L.C.R.-Z., N.V., and P.H. critically reviewed the manuscript. All authors have read and agreed to the published version of the manuscript.

Funding: This research was supported by the CONACYT project FC 1572, Grant Agency of the Czech Republic (Grant nos. 19-05608S and 18-19714S); by the Czech Academy of Sciences (Grant no. JSPS-20-06); by the Institutional Research Concept of the Institute of Molecular Genetics (Grant no. RVO: 68378050); by the MEYS CR (COST Inter-excellence internship LTC19048) and the project: BIOCEV - Biotechnology and Biomedicine Centre of the Academy of Sciences and Charles University" (CZ.1.05/1.1.00/02.0109), from the European Regional Development Fund. The Microscopy Centre was supported by the MEYS CR (LM2018129 Czech-BioImaging) and by the 
European Regional Development Fund-Project "Modernization and support of research activities of the national infrastructure for biological and medical imaging CzechBioImaging" (no. CZ.02.1.01/0.0/0.0/16_013/0001775)., and the CONACYT fellowship to FGC with number 576664.

Acknowledgments: We would like to thank Michaela Blažíková and Ivan Novotný for their excellent help in protein dynamics as well as Pavel Kř́žz, Angela Ku, and Wilma Gonzalez for their technical help. Lisa DeTora provided editorial advice for manuscript revisions after peer review.

Conflicts of Interest: The authors declare that they have no conflicts of interest with the contents of this article.

\section{References}

1. Schimmang, T.; Tollervey, D.; Kern, H.; Frank, R.; Hurt, E.C. A yeast nucleolar protein related to mammalian fibrillarin is associated with small nucleolar RNA and is essential for viability. EMBO J. 1989, 8, 4015-4024. [CrossRef] [PubMed]

2. Hernandez-Verdun, D.; Roussel, P.; Thiry, M.; Sirri, V.; Lafontaine, D.L.J. The nucleolus: Structure/function relationship in RNA metabolism. Wiley Interdiscip. Rev. RNA 2010, 1, 415-431. [CrossRef] [PubMed]

3. Narayanan, A.; Speckmann, W.; Terns, R.; Terns, M.P. Role of the Box C/D Motif in Localization of Small Nucleolar RNAs to Coiled Bodies and Nucleoli. Mol. Biol. Cell 1999, 10, 2131-2147. [CrossRef] [PubMed]

4. Weber, S.C.; Brangwynne, C.P. Inverse size scaling of the nucleolus by a concentration-dependent phase transition. Curr. Biol. 2015, 25, 641-646. [CrossRef] [PubMed]

5. Brangwynne, C.P.; Mitchison, T.J.; Hyman, A.A. Active liquid-like behavior of nucleoli determines their size and shape in Xenopus laevis oocytes. Proc. Natl. Acad. Sci. USA 2011, 108, 4334-4339. [CrossRef] [PubMed]

6. Falahati, H.; Wieschaus, E. Independent active and thermodynamic processes govern the nucleolus assembly in vivo. Proc. Natl. Acad. Sci. USA 2017, 114, 1335-1340. [CrossRef]

7. Berry, J.; Weber, S.C.; Vaidya, N.; Haataja, M.; Brangwynne, C.P. RNA transcription modulates phase transition-driven nuclear body assembly. Proc. Natl. Acad. Sci. USA 2015, 112, E5237-E5245. [CrossRef]

8. Mitrea, D.M.; Kriwacki, R.W. Phase separation in biology; functional organization of a higher order. Cell Commun. Signal. 2016, 14, 1. [CrossRef]

9. Mitrea, D.M.; Cika, J.A.; Stanley, C.B.; Nourse, A.; Onuchic, P.L.; Banerjee, P.R.; Phillips, A.H.; Park, C.G.; Deniz, A.A.; Kriwacki, R.W. Self-interaction of NPM1 modulates multiple mechanisms of liquid-liquid phase separation. Nat. Commun. 2018, 9, 1-13. [CrossRef]

10. Rodriguez-Corona, U.; Sobol, M.; Rodriguez-Zapata, L.C.; Hozak, P.; Castano, E. Fibrillarin from Archaea to human. Biol. Cell 2015, 107, 159-174. [CrossRef]

11. Aris, J.P.; Blobel, G. cDNA cloning and sequencing of human fibrillarin, a conserved nucleolar protein recognized by autoimmune antisera. Proc. Natl. Acad. Sci. USA 1991, 88, 931-935. [CrossRef] [PubMed]

12. Tessarz, P.; Santos-Rosa, H.; Robson, S.C.; Sylvestersen, K.B.; Nelson, C.J.; Nielsen, M.L.; Kouzarides, T. Glutamine methylation in histone $\mathrm{H} 2 \mathrm{~A}$ is an RNA-polymerase-I-dedicated modification. Nature 2014, 505, 564-568. [CrossRef] [PubMed]

13. Loza-Muller, L.; Rodríguez-Corona, U.; Sobol, M.; Rodríguez-Zapata, L.C.; Hozak, P.; Castano, E. Fibrillarin methylates H2A in RNA polymerase I trans-active promoters in Brassica oleracea. Front. Plant Sci. 2015, 6, 976. [CrossRef]

14. Chen, H.; Wurm, T.; Britton, P.; Brooks, G.; Hiscox, J.A. Interaction of the coronavirus nucleoprotein with nucleolar antigens and the host cell. J. Virol. 2002, 76, 5233-5250. [CrossRef] [PubMed]

15. Ponti, D.; Troiano, M.; Bellenchi, G.C.; Battaglia, P.A.; Gigliani, F. The HIV Tat protein affects processing of ribosomal RNA precursor. BMC Cell Biol. 2008, 9, 32. [CrossRef] [PubMed]

16. Melén, K.; Tynell, J.; Fagerlund, R.; Roussel, P.; Hernandez-Verdun, D.; Julkunen, I. Influenza A H3N2 subtype virus NS1 protein targets into the nucleus and binds primarily via its C-terminal NLS2/NoLS to nucleolin and fibrillarin. Virol. J. 2012, 9, 167. [CrossRef]

17. Fournier, M.J.; Maxwell, E.S. The nucleolar snRNAs: Catching up with the spliceosomal snRNAs. Trends Biochem. Sci. 1993, 18, 131-135. [CrossRef]

18. Kass, S.; Tyc, K.; Steitz, J.A.; Sollner-Webb, B. The U3 small nucleolar ribonucleoprotein functions in the first step of preribosomal RNA processing. Cell 1990, 60, 897-908. [CrossRef] 
19. Hughes, J.M.; Ares, M. Depletion of U3 small nucleolar RNA inhibits cleavage in the $5^{\prime}$ external transcribed spacer of yeast pre-ribosomal RNA and impairs formation of 18 S ribosomal RNA. EMBO J. 1991, 10, 4231-4239. [CrossRef]

20. Dragon, F.; Lemay, V.; Trahan, C. snoRNAs: Biogenesis, structure and function. Encycl. Life Sci. 2006, 1-7. [CrossRef]

21. Granneman, S.; Vogelzangs, J.; Lührmann, R.; van Venrooij, W.J.; Pruijn, G.J.M.; Watkins, N.J. Role of pre-rRNA base pairing and $80 \mathrm{~S}$ complex formation in subnucleolar localization of the U3 snoRNP. Mol. Cell. Biol. 2004, 24, 8600-8610. [CrossRef]

22. Sáez-Vasquez, J.; Caparros-Ruiz, D.; Barneche, F.; Echeverría, M. Characterization of a crucifer plant pre-rRNA processing complex. Biochem. Soc. Trans. 2004, 32, 578-580. [CrossRef] [PubMed]

23. Lin, Y.; Protter, D.S.W.; Rosen, M.K.; Parker, R. Formation and maturation of phase-separated liquid droplets by RNA-binding proteins. Mol. Cell 2015, 60, 208-219. [CrossRef] [PubMed]

24. Smith, D.-L.; Erce, M.A.; Lai, Y.-W.; Tomasetig, F.; Hart-Smith, G.; Hamey, J.J.; Wilkins, M.R. Crosstalk of phosphorylation and arginine methylation in disordered SRGG repeats of S. cerevisiae fibrillarin and its association with nucleolar localisation. J. Mol. Biol. 2019, 432, 448-466. [CrossRef] [PubMed]

25. Yildirim, S.; Castano, E.; Sobol, M.; Philimonenko, V.V.; Dzijak, R.; Venit, T.; Hozak, P.; Hozák, P. Involvement of phosphatidylinositol 4,5-bisphosphate in RNA polymerase I transcription. J. Cell Sci. 2013, 126, 2730-2739. [CrossRef] [PubMed]

26. Sobol, M.; Yildirim, S.; Philimonenko, V.V.; Marášek, P.; Castaño, E.; Hozák, P. UBF complexes with phosphatidylinositol 4,5-bisphosphate in nucleolar organizer regions regardless of ongoing RNA polymerase I activity. Nucleus 2013, 4, 478-486. [CrossRef] [PubMed]

27. Hamann, B.L.; Blind, R.D. Nuclear phosphoinositide regulation of chromatin. J. Cell. Physiol. 2017, 233, 107-123. [CrossRef]

28. Castano, E.; Yildirim, S.; Fáberová, V.; Krausová, A.; Uličná, L.; Paprčková, D.; Sztacho, M.; Hozák, P. Nuclear phosphoinositides-Versatile regulators of genome functions. Cells 2019, 8, 649. [CrossRef]

29. Kalasova, I.; Fáberová, V.; Kalendová, A.; Yildirim, S.; Uličná, L.; Venit, T.; Hozák, P. Tools for visualization of phosphoinositides in the cell nucleus. Histochem. Cell Biol. 2016, 145, 485-496. [CrossRef]

30. Sobol, M.; Krausová, A.; Yildirim, S.; Kalasová, I.; Fáberová, V.; Vrkoslav, V.; Philimonenko, V.; Marášek, P.; Pastorek, L.; Čapek, M.; et al. Nuclear phosphatidylinositol 4,5-bisphosphate islets contribute to efficient RNA polymerase II-dependent transcription. J. Cell Sci. 2018, 131, jcs211094. [CrossRef]

31. Arraiano, C.M.; Mauxion, F.; Viegas, S.C.; Matos, R.G.; Séraphin, B. Intracellular ribonucleases involved in transcript processing and decay: Precision tools for RNA. Biochim. Biophys. Acta 2013, 1829, 491-513. [CrossRef] [PubMed]

32. Deutscher, M.P. Twenty years of bacterial RNases and RNA processing: How we've matured. RNA 2015, 21, 597-600. [CrossRef] [PubMed]

33. Moelling, K.; Broecker, F. The reverse transcriptase-RNase H: From viruses to antiviral defense. Ann. N. Y. Acad. Sci. 2015, 1341, 126-135. [CrossRef] [PubMed]

34. Bubeck, D.; Reijns, M.A.M.; Graham, S.C.; Astell, K.R.; Jones, E.Y.; Jackson, A.P. PCNA directs type 2 RNase $\mathrm{H}$ activity on DNA replication and repair substrates. Nucleic Acids Res. 2011, 39, 3652-3666. [CrossRef] [PubMed]

35. Houseley, J.; Tollervey, D. The many pathways of RNA degradation. Cell 2009, 136, 763-776. [CrossRef] [PubMed]

36. Henras, A.K.; Plisson-Chastang, C.; O’Donohue, M.F.; Chakraborty, A.; Gleizes, P.E. An overview of pre-ribosomal RNA processing in eukaryotes. Wiley Interdiscip. Rev. RNA 2015, 6, 225-242. [CrossRef]

37. Fatica, A.; Galardi, S.; Altieri, F.; Bozzoni, I. Fibrillarin binds directly and specifically to U16 box C/D snoRNA. RNA 2000, 6, 88-95. [CrossRef]

38. Tschochner, H.; Hurt, E. Pre-ribosomes on the road from the nucleolus to the cytoplasm. Trends Cell Biol. 2003, 13, 255-263. [CrossRef]

39. Kassas, N.; Tanguy, E.; Thahouly, T.; Fouillen, L.; Heintz, D.; Chasserot-Golaz, S.; Bader, M.-F.; Grant, N.J.; Vitale, N. Comparative characterization of phosphatidic acid sensors and their localization during frustrated phagocytosis. J. Biol. Chem. 2017, 292, 4266-4279. [CrossRef]

40. Ulrich, A.; Andersen, K.R.; Schwartz, T.U. Exponential Megapriming PCR (EMP) Cloning-Seamless DNA Insertion into Any Target Plasmid without Sequence Constraints. PLoS ONE 2012, 7, e0053360. [CrossRef] 
41. Peng, Y.; Yu, G.; Tian, S.; Li, H. Co-expression and co-purification of archaeal and eukaryal box C/D RNPs. PLoS ONE 2014, 9, e0103096. [CrossRef] [PubMed]

42. Dudkina, E.; Ulyanova, V.; Shah Mahmud, R.; Khodzhaeva, V.; Dao, L.; Vershinina, V.; Kolpakov, A.; Ilinskaya, $\mathrm{O}$. Three-step procedure for preparation of pure Bacillus altitudinis ribonuclease. FEBS Open Bio 2016, 6, 24-32. [CrossRef] [PubMed]

43. Chen, D.; Huang, S. Nucleolar components involved in ribosome biogenesis cycle between the nucleolus and nucleoplasm in interphase cells. J. Cell Biol. 2001, 153, 169-176. [CrossRef] [PubMed]

44. Altschul, S.F.; Koonin, E.V. Iterated profile searches with PSI-BLAST-a tool for discovery in protein databases. Trends Biochem. Sci. 1998, 23, 444-447. [CrossRef]

45. Rosenhouse-Dantsker, A.; Logothetis, D.E.; Levitan, I. Cholesterol sensitivity of KIR2.1 is controlled by a belt of residues around the cytosolic pore. Biophys. J. 2011, 100, 381-389. [CrossRef]

46. Morales, J.; Sobol, M.; Rodriguez-Zapata, L.C.; Hozak, P.; Castano, E. Aromatic amino acids and their relevance in the specificity of the PH domain. J. Mol. Recognit. 2017, 30. [CrossRef]

47. Min, J.; Wu, H.; Zeng, H.; Loppnau, P.; Weigelt, J.; Sundstrom, M.; Arrowsmith, C.H.; Edwards, A.M.; Bochkarev, A.; Plotnikov, A.N.; et al. Resour. Stud. Biol. Macromol. Protein Data Bank. Available online: https://www.rcsb.org/structure/2IPX. (accessed on 20 April 2019).

48. Schwarz, D.S.; Blower, M.D. The calcium-dependent ribonuclease XendoU promotes ER network formation through local RNA degradation. J. Cell Biol. 2014, 207, 41-57. [CrossRef] [PubMed]

49. Seidel, C.W.; Peck, L.J. Purification of a calcium dependent ribonuclease from Xenopus laevis. Nucleic Acids Res. 1994, 22, 1456-1462. [CrossRef]

50. Rosta, E.; Yang, W.; Hummer, G. Calcium inhibition of ribonuclease H1 two-metal ion catalysis. J. Am. Chem. Soc. 2014, 136, 3137-3144. [CrossRef]

51. Rodriguez-Corona, U.; Pereira-Santana, A.; Sobol, M.; Rodriguez-Zapata, L.C.; Hozak, P.; Castano, E. Novel Ribonuclease Activity Differs between Fibrillarins from Arabidopsis thaliana. Front. Plant Sci. 2017, 8, 1878. [CrossRef]

52. Tran, E.J.; Zhang, X.; Maxwell, E.S. Efficient RNA 2'-O-methylation requires juxtaposed and symmetrically assembled archaeal box C/D and C'/D' RNPs. EMBO J. 2003, 22, 3930-3940. [CrossRef] [PubMed]

53. Watkins, N.J.; Bohnsack, M.T. The box C/D and H/ACA snoRNPs: Key players in the modification, processing and the dynamic folding of ribosomal RNA. Wiley Interdiscip. Rev. RNA 2012, 3, 397-414. [CrossRef] [PubMed]

54. Newman, D.R.; Kuhn, J.F.; Shanab, G.M.; Maxwell, E.S. Box C/D snoRNA-associated proteins: Two pairs of evolutionarily ancient proteins and possible links to replication and transcription. RNA 2000, 6, 861-879. [CrossRef] [PubMed]

55. Tomkuviene, M.; Ličyte, J.; Olendraite, I.; Liutkevičiute, Z.; Clouet-D’Orval, B.; Klimašauskas, S. Archaeal fibrillarin-Nop5 heterodimer 2'-O-methylates RNA independently of the C/D guide RNP particle. RNA 2017, 23, 1329-1337. [CrossRef]

56. Thandapani, P.; O'Connor, T.R.; Bailey, T.L.; Richard, S. Defining the RGG/RG Motif. Mol. Cell 2013, 50, 613-623. [CrossRef]

57. McBride, A.E.; Conboy, A.K.; Brown, S.P.; Ariyachet, C.; Rutledge, K.L. Specific sequences within arginine-glycine-rich domains affect mRNA-binding protein function. Nucleic Acids Res. 2009, 37, 4322-4330. [CrossRef]

58. Gendra, E.; Moreno, A.; Albà, M.M.; Pages, M. Interaction of the plant glycine-rich RNA-binding protein MA16 with a novel nucleolar DEAD box RNA helicase protein from Zea mays. Plant J. 2004, 38, 875-886. [CrossRef]

59. Donald, R.G.; Lawrence, D.M.; Jackson, A.O. The barley stripe mosaic virus 58-kilodalton beta (b) protein is a multifunctional RNA binding protein. J. Virol. 1997, 71, 1538-1546. [CrossRef]

60. Lawrence, D.M.; Jackson, A.O. Requirements for cell-to-cell movement of Barley stripe mosaic virus in monocot and dicot hosts. Mol. Plant Pathol. 2001, 2, 65-75. [CrossRef]

61. Lawrence, D.M.; Jackson, A.O. Interactions of the TGB1 protein during cell-to-cell movement of Barley stripe mosaic virus. J. Virol. 2001, 75, 8712-8723. [CrossRef]

62. Li, Z.; Zhang, Y.; Jiang, Z.; Jin, X.; Zhang, K.; Wang, X.; Han, C.; Yu, J.; Li, D. Hijacking of the nucleolar protein fibrillarin by TGB1 is required for cell-to-cell movement of Barley stripe mosaic virus. Mol. Plant Pathol. 2018, 19, 1222-1237. [CrossRef] [PubMed] 
63. Kim, S.H.; Macfarlane, S.; Kalinina, N.O.; Rakitina, D.V.; Ryabov, E.V.; Gillespie, T.; Haupt, S.; Brown, J.W.S.; Taliansky, M. Interaction of a plant virus-encoded protein with the major nucleolar protein fibrillarin is required for systemic virus infection. Proc. Natl. Acad. Sci. USA 2007, 104, 11115-11120. [CrossRef] [PubMed]

64. Emmott, E.; Hiscox, J.A. Nucleolar targeting: The hub of the matter. EMBO Rep. 2009, 10, 231-238. [CrossRef] [PubMed]

65. Dixon, S.E.; Bhatti, M.M.; Uversky, V.N.; Dunker, A.K.; Sullivan, W.J., Jr. Regions of intrinsic disorder help identify a novel nuclear localization signal in Toxoplasma gondii histone acetyltransferase TgGCN5-B. Mol. Biochem. Parasitol. 2011, 175, 192-195. [CrossRef]

66. Jansen, R.P.; Hurt, E.C.; Kern, H.; Lehtonen, H.; Carmo-Fonseca, M.; Lapeyre, B.; Tollervey, D. Evolutionary conservation of the human nucleolar protein fibrillarin and its functional expression in yeast. J. Cell Biol. 1991, 113, 715-729. [CrossRef] [PubMed]

67. Tollervey, D.; Lehtonen, H.; Jansen, R.; Kern, H.; Hurt, E.C. Temperature-sensitive mutations demonstrate roles for yeast fibrillarin in pre-rRNA processing, pre-rRNA methylation, and ribosome assembly. Cell 1993, 72, 443-457. [CrossRef]

68. Peña, C.; Hurt, E.; Panse, V.G. Eukaryotic ribosome assembly, transport and quality control. Nat. Struct. Mol. Biol. 2017, 24, 689-699. [CrossRef]

69. Correll, C.C.; Bartek, J.; Dundr, M. The Nucleolus: A multiphase condensate balancing ribosome synthesis and translational capacity in health, aging and ribosomopathies. Cells 2019, 8, 869. [CrossRef]

70. Yao, R.-W.; Xu, G.; Wang, Y.; Shan, L.; Luan, P.-F.; Wang, Y.; Wu, M.; Yang, L.-Z.; Xing, Y.-H.; Yang, L.; et al. Nascent Pre-rRNA Sorting via Phase Separation Drives the Assembly of Dense Fibrillar Components in the Human Nucleolus. Mol. Cell 2019, 76, 767-783. [CrossRef]

71. Xing, Y.-H.; Yao, R.-W.; Zhang, Y.; Guo, C.-J.; Jiang, S.; Xu, G.; Dong, R.; Yang, L.; Chen, L.-L. SLERT Regulates DDX21 Rings Associated with Pol I Transcription. Cell 2017, 169, 664-678.e16. [CrossRef]

72. Tollervey, D.; Lehtonen, H.; Carmo-Fonseca, M.; Hurt, E.C. The small nucleolar RNP protein NOP1 (fibrillarin) is required for pre-rRNA processing in yeast. EMBO J. 1991, 10, 573-583. [CrossRef] [PubMed]

73. Tiku, V.; Kew, C.; Mehrotra, P.; Ganesan, R.; Robinson, N.; Antebi, A. Nucleolar fibrillarin is an evolutionarily conserved regulator of bacterial pathogen resistance. Nat. Commun. 2018, 9, 3607. [CrossRef] [PubMed]

74. Seo, J.S.; Diloknawarit, P.; Park, B.S.; Chua, N.H. ELF18-INDUCED LONG NONCODING RNA 1 evicts fibrillarin from mediator subunit to enhance PATHOGENESIS-RELATED GENE 1 (PR1) expression. New Phytol. 2019, 221, 2067-2079. [CrossRef] [PubMed]

75. Lapeyre, B.; Bourbon, H.; Amalric, F. Nucleolin, the major nucleolar protein of growing eukaryotic cells: An unusual protein structure revealed by the nucleotide sequence. Proc. Natl. Acad. Sci. USA 1987, 84, 1472-1476. [CrossRef]

76. Lee, W.C.; Xue, Z.X.; Mélèse, T. The NSR1 gene encodes a protein that specifically binds nuclear localization sequences and has two RNA recognition motifs. J. Cell Biol. 1991, 113, 1-12. [CrossRef]

77. Jong, A.Y.; Clark, M.W.; Gilbert, M.; Oehm, A.; Campbell, J.L. Saccharomyces cerevisiae SSB1 protein and its relationship to nucleolar RNA-binding proteins. Mol. Cell. Biol. 1987, 7, 2947-2955. [CrossRef]

78. Girard, J.P.; Lehtonen, H.; Caizergues-Ferrer, M.; Amalric, F.; Tollervey, D.; Lapeyre, B. GAR1 is an essential small nucleolar RNP protein required for pre-rRNA processing in yeast. EMBO J. 1992, 11, 673-682. [CrossRef]

79. Bugler, B.; Bourbon, H.; Lapeyre, B.; Wallace, M.O.; Chang, J.H.; Amalric, F.; Olson, M.O. RNA binding fragments from nucleolin contain the ribonucleoprotein consensus sequence. J. Biol. Chem. 1987, 262, 10922-10925.

80. Snaar, S.; Wiesmeijer, K.; Jochemsen, A.G.; Tanke, H.J.; Dirks, R.W. Mutational analysis of fibrillarin and its mobility in living human cells. J. Cell Biol. 2000, 151, 653-662. [CrossRef]

81. Fiume, R.; Keune, W.J.; Faenza, I.; Bultsma, Y.; Ramazzotti, G.; Jones, D.R.; Martelli, A.M.; Somner, L.; Follo, M.Y.; Divecha, N.; et al. Nuclear phosphoinositides: Location, regulation and function. Subcell. Biochem. 2012, 59, 335-361.

82. Sagaram, U.S.; El-Mounadi, K.; Buchko, G.W.; Berg, H.R.; Kaur, J.; Pandurangi, R.S.; Smith, T.J.; Shah, D.M. Structural and functional studies of a phosphatidic acid-binding antifungal plant defensin MtDef4: Identification of an RGFRRR motif governing fungal cell entry. PLoS ONE 2013, 8, e82485. [CrossRef] [PubMed] 
83. Wawrzyniak, A.M.; Kashyap, R.; Zimmermann, P. Phosphoinositides and PDZ domain scaffolds. Adv. Exp. Med. Biol. 2013, 991, 41-57. [PubMed]

84. Warner, J.R. The economics of ribosome biosynthesis in yeast. Trends Biochem. Sci. 1999, 24, 437-440. [CrossRef]

(c) (C) 2020 by the authors. Licensee MDPI, Basel, Switzerland. This article is an open access article distributed under the terms and conditions of the Creative Commons Attribution (CC BY) license (http://creativecommons.org/licenses/by/4.0/). 